\title{
Nature and Evolution of the Ore-Forming Fluids from Nanmushu Carbonate-Hosted Zn-Pb Deposit in the Mayuan District, Shaanxi Province, Southwest China
}

\author{
Suo-Fei Xiong, ${ }^{1}$ Yong-Jun Gong, ${ }^{1}$ Shu-Zhen Yao, ${ }^{1}$ \\ Chuan-Bo Shen, ${ }^{1}$ Xiang Ge, ${ }^{1}$ and Shao-Yong Jiang ${ }^{1,2}$ \\ ${ }^{1}$ State Key Laboratory of Geological Processes and Mineral Resources, Faculty of Earth Resources and Collaborative Innovation \\ Center for Exploration of Strategic Mineral Resources, China University of Geosciences, Wuhan 430074, China \\ ${ }^{2}$ State Key Laboratory for Mineral Deposits Research, Department of Earth Sciences, Nanjing University, Nanjing 210093, China
}

Correspondence should be addressed to Shao-Yong Jiang; shyjiang@cug.edu.cn

Received 5 May 2017; Revised 21 August 2017; Accepted 24 October 2017; Published 21 November 2017

Academic Editor: Sabina S. Palinkas

Copyright (c) 2017 Suo-Fei Xiong et al. This is an open access article distributed under the Creative Commons Attribution License, which permits unrestricted use, distribution, and reproduction in any medium, provided the original work is properly cited.

\begin{abstract}
The Nanmushu carbonate-hosted $\mathrm{Zn}-\mathrm{Pb}$ deposit is located in the Mayuan district of Shaanxi Province, a newly discovered metallogenic district next to the Sichuan Basin, in the northern margin of the Yangtze Block, which is the largest and the only one that is currently mined in this district. The $\delta^{34} \mathrm{~S}$ values of sulfides are characterized by positive values with a peak around $+18 \%$, and the reduced sulfur may have derived from reduction of $\mathrm{SO}_{4}{ }^{2-}$ from paleoseawater or evaporitic sulfates that have possibly been leached by basinal brines during mineralization stage. Detailed fluid inclusion study shows two types of fluids in the sphalerite, quartz, dolomite, calcite and barite, that is, aqueous-salt dominant inclusions (type I) and hydrocarbon-bearing inclusions (type II). The Laser Raman spectroscopy study shows occurrence of certain amount of $\mathrm{CH}_{4}, \mathrm{C}_{4} \mathrm{H}_{6}$, and bitumen. The salinities show similar values around 6 to $12 \mathrm{wt} \% \mathrm{NaCl}$ equivalent but a decreasing temperature from early to late stages (typically $200^{\circ}$ to $320^{\circ} \mathrm{C}$ in stage $\mathrm{I}, 180^{\circ}$ to $260^{\circ} \mathrm{C}$ in stage II, and $140^{\circ}$ to $180^{\circ} \mathrm{C}$ in stage III). These features may be related to basinal brines mixing between an external higher salinity $\mathrm{CaCl}_{2} \pm \mathrm{MgCl}_{2}$-rich fluid and a local $\mathrm{H}_{2} \mathrm{O}-\mathrm{NaCl}$ methane-rich fluid.
\end{abstract}

\section{Introduction}

Carbonate-hosted $\mathrm{Zn}-\mathrm{Pb}$ deposit is one of the most important $\mathrm{Pb}$ and $\mathrm{Zn}$ producers in the world; however, the detailed ore-forming processes are still ambiguous, especially when carbonate-hosted $\mathrm{Zn}-\mathrm{Pb}$ deposit is spatially associated with organic matter in or next to sedimentary basins. The close relationship between carbonate-hosted $\mathrm{Zn}-\mathrm{Pb}$ deposits and hydrocarbon reservoirs in a sedimentary basin has been widely noted [1-4], but the detailed metallogenic mechanism remains poorly understood.

The Mayuan district, in the northern margin of the Yangtze Block (Figure 1), next to the Sichuan Basin, is a newly discovered $\mathrm{Zn}-\mathrm{Pb}$ ore concentrated area with large economic significance. Since the discovery of these deposits in 2004, only few researches have been carried out and the ore genesis remains controversial. Qi et al. [5] suggested a stratabound syn-sedimentary hydrothermal origin for these $\mathrm{Zn}-\mathrm{Pb}$ deposits, according to geological characteristics of all orebodies hosted in the Neoproterozoic Dengying Formation dolomite. Chen et al. [6] claimed that the Dengying Formation dolomite may have been influenced by hydrothermal fluids on account of trace elements and REEs data. Other researchers [7-11] suggested that these deposits belong to the Mississippi Valley-type (MVT) Zn-Pb deposit based on the fluid inclusion and isotope geochemical data. Previous microthermometry measurements show that fluid inclusions of hydrothermal epoch homogenized in temperatures between 98 and $337^{\circ} \mathrm{C}$ [8]. Based on H-O-C-He-Ar-Sr isotope data, Gao et al. [11] proposed that the $\mathrm{Zn}-\mathrm{Pb}$ deposits in the Mayuan district may have precipitated from a mixture of crustal fluid and meteoric water. Gao et al. [11] put forward a hypothesis of organic fluid origin for ore fluids based on the low $\delta^{13} \mathrm{C}$ values (from -36.0 to $-28.3 \%$ for $\delta^{13} \mathrm{C}_{\mathrm{CH} 4}$ 

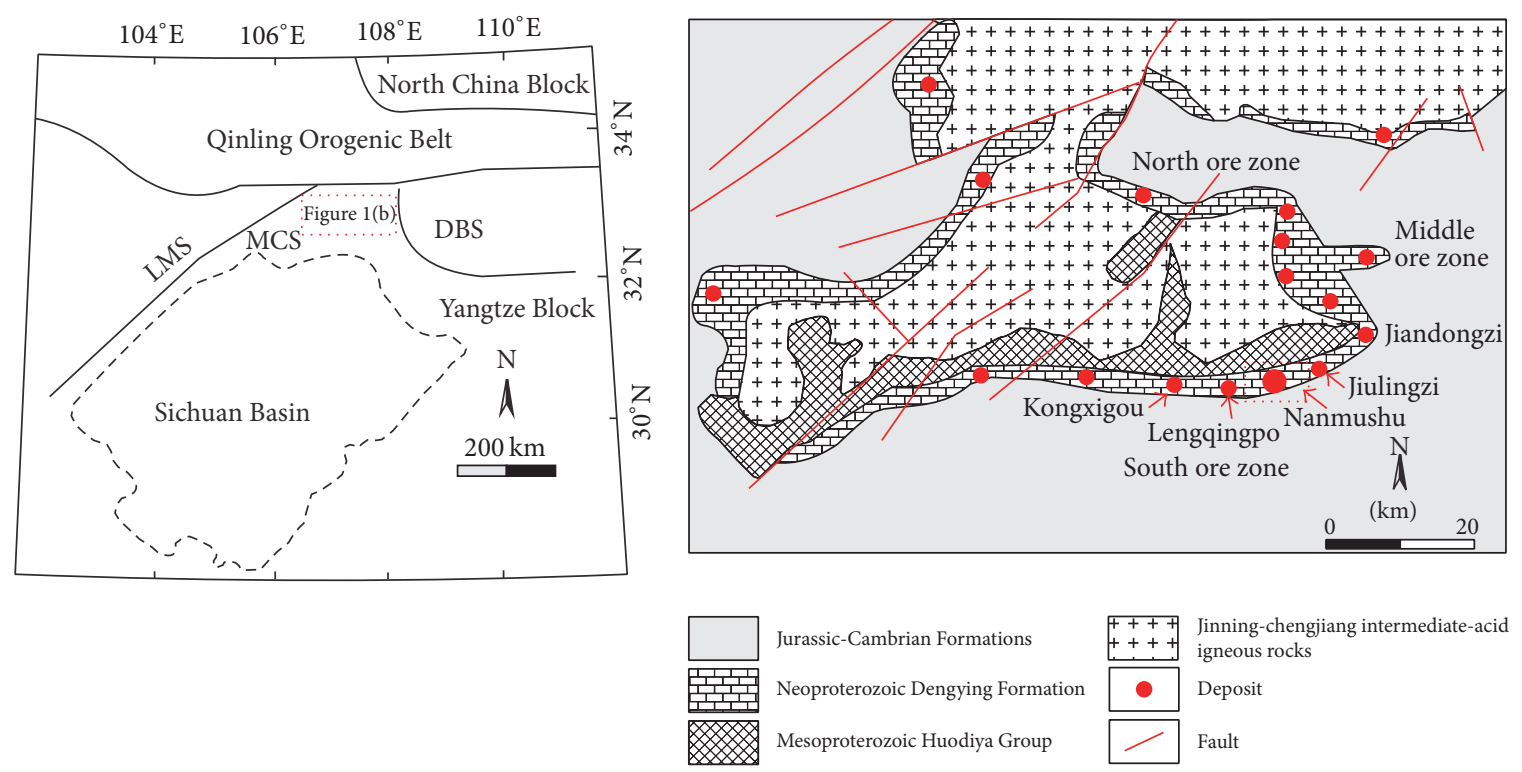

(a)

(b)

Figure 1: (a) Tectonic location of the Mayuan district. (b) The distribution of the South, Middle, and North ore zones, and major $\mathrm{Zn}-\mathrm{Pb}$ deposits in the Mayuan district (modified from Hou et al., 2007 [23]). MCS, Micangshan fold-and-thrust belt; LMS, Longmenshan fold-andthrust belt; DBS, Dabashan fold-and-thrust belt.

and from -27.7 to $-22.4 \%$ for $\delta^{13} \mathrm{C}_{\mathrm{C} 2 \mathrm{H} 6}$, resp.) of fluid inclusion in the sphalerite, which are similar to the $\delta^{13} \mathrm{C}$ values of the gas reservoir in the Dengying Formation. In this deposit, hand specimen and microscopic-scale thin sections of the sulfide ores show a spatial association with bitumen $[7,8,10]$. However, the characteristics of the organic-rich fluids, the link between the organic-rich fluids, mechanisms by which the ore-forming fluids make sphalerite and galena precipitated, and the controlling factors of mineralization are still ambiguous.

There are three ore zones (North, Middle, and South) in the Mayuan district [5]. Metallogenic prospecting of the North and Middle zones is $1.0 \mathrm{Mt}$ and $1.5 \mathrm{Mt}$, respectively. Further prospecting work has not started yet in the North and Middle zones. The South zone is the only one that is being currently mined in the Mayuan district. There are a series of occurrences of the $\mathrm{Zn}-\mathrm{Pb}$ deposits in the South zone, among which the Nanmushu deposit is the largest one (Figure 1). The study of ore-forming fluid is an effective way to trace the ore-forming process and can provide effective information about mineralization [12-15]. In this paper, the Nanmushu deposit was selected for a detailed fluid inclusion study, and our results demonstrate a carbonate-hosted Zn$\mathrm{Pb}$ deposit may have formed by mixing of high salinity brines into a local $\mathrm{H}_{2} \mathrm{O}-\mathrm{NaCl}$ methane-rich fluid. In addition, here we also present a detailed geological and sulfur isotope study and, combined with fluid inclusion study for the Nanmushu deposit, it can provide a better understanding of the nature and origin of the ore-forming fluids and the ore genesis. These results can also provide new insights into the mechanisms that formed the ore deposits with hydrocarbonbearing fluids. Although this approach does not attempt to explain all the deposit features in this district, it will possibly provide a reasonably detailed new understanding for a typical deposit in the Mayuan district.

\section{Geological Background}

2.1. Regional Geology. The Yangtze Block is separated from the North China Block by the Qinling Orogenic Belt (Figure 1(a)). The Yangtze Block is composed of Archean to Early Proterozoic basements, Mesoproterozoic folded basement, and Neoproterozoic to Mesozoic cover sequences [18-21]. The thick cover of Neoproterozoic to Permian strata is over $9 \mathrm{~km}$, which comprises glacial deposits, clastic, metavolcanic rocks, and carbonate. Abundant carbonate-hosted $\mathrm{Zn}-\mathrm{Pb}$ deposits are located in the northern belt of the Yangtze Block [22].

The Mayuan district is a newly discovered $\mathrm{Zn}-\mathrm{Pb}$ metallogenic district, located in the northern margin of Yangtze Block, next to Sichuan Basin. This district is also located at the junction of the Qinling Orogenic Belt to the South of Yangtze Block and along the eastern margin of the Micangshan fold-and-thrust belt (Figure 1(a)). The Mayuan $\mathrm{Zn}-\mathrm{Pb}$ metallogenic district includes three ore zones, namely, the South, Middle, and North zones (Figure 1(b)). The South ore zone extends over $20 \mathrm{~km}$ and broadens 20 to $120 \mathrm{~m}$ with approximately $2.1 \mathrm{Mt} \mathrm{Zn}$ (with a grade of $1.2-4.5 \mathrm{wt} . \%$ ) and $0.1 \mathrm{Mt} \mathrm{Pb}$ (with a grade of $0.6-3.5 \mathrm{wt} . \%$ ). This ore zone contains five deposits including Kongxigou, Lengqingpo, Nanmushu, Jiulingzi, and Jiandongzi from SWW to NEE $[17,23]$.

2.2. Geology of the Nanmushu $\mathrm{Zn}-\mathrm{Pb}$ Deposit. The Nanmushu $\mathrm{Zn}-\mathrm{Pb}$ deposit is located in the central part of the South 

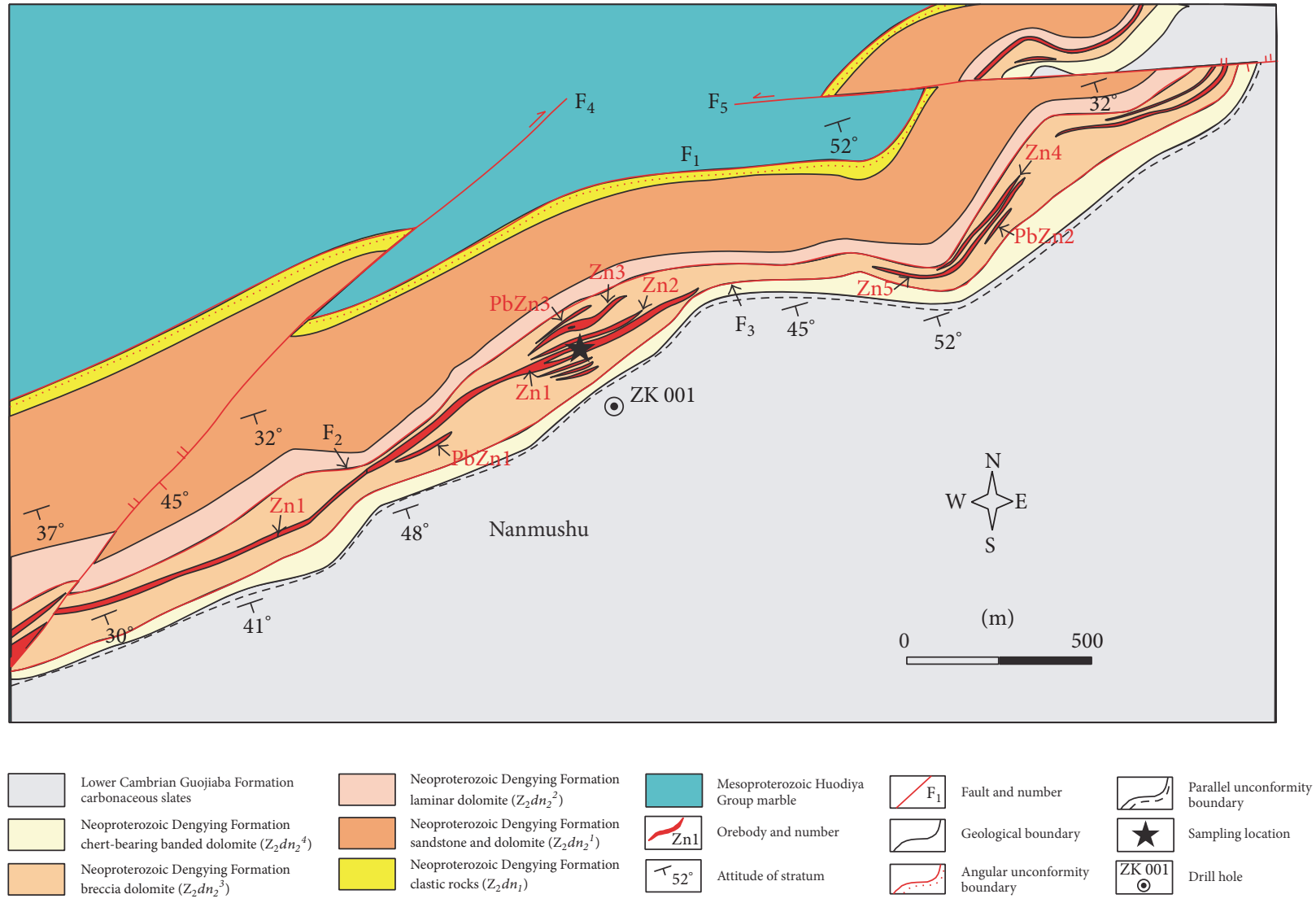

Figure 2: Geological map of the Nanmushu Zn-Pb deposit showing the orebodies are mainly hosted in the third section of Neoproterozoic Dengying Formation breccia dolomite $\left(\mathrm{Z}_{2} d n_{2}{ }^{3}\right)$ (after Han et al., 2016 [10]).

ore zone (Figure $1(\mathrm{~b}))$. In the deposit, the outcropped strata consist of Mesoproterozoic Huodiya Group, Neoproterozoic Dengying Formation, and the Lower Cambrian Guojiaba Formation (Figure 2). The Huodiya Group is mainly composed of marbles, pyroclastic rocks, and siliceous slates, and the most common rocks of the Huodiya Group in this area are marbles. This group is unconformably overlain by the Neoproterozoic Dengying Formation carbonate rocks which mainly include dolomites with minor amount of quartz sandstones and limestones, whereas the Lower Cambrian Guojiaba Formation is characterized by argillaceous limestones and carbonaceous slates. The Dengying Formation in the study area can be subdivided into the lower member $\left(\mathrm{Z}_{2} d n_{1}\right)$ and the upper member $\left(\mathrm{Z}_{2} d n_{2}{ }^{1-4}\right)$ (Figure 2). $\mathrm{Z}_{2} d n_{1}$ (31 to $50 \mathrm{~m}$ thick) is characterized by clastic rocks, sandstone, and conglomerate. $\mathrm{Z}_{2} d n_{2}{ }^{1-4}$ can be further subdivided into four beds from the bottom upward: the first bed $\left(\mathrm{Z}_{2} d n_{2}{ }^{1}, 350\right.$ to $450 \mathrm{~m}$ thick) consists of off-white fine-crystalline dolomite, sandstone, and pebbly sandstone; the second bed $\left(\mathrm{Z}_{2} d n_{2}{ }^{2}\right.$, 40 to $80 \mathrm{~m}$ thick) contains gray laminar algal dolomite and gray-white laminar dolomite; the third bed $\left(\mathrm{Z}_{2} d n_{2}{ }^{3}, 78\right.$ to $120 \mathrm{~m}$ thick) comprises banded dolomite, breccia dolomite, and dolorudite, which hosted major orebodies in the Nanmushu deposit; the fourth bed $\left(\mathrm{Z}_{2} d n_{2}{ }^{4}, 35\right.$ to $50 \mathrm{~m}$ thick) is dominated by chert-bearing banded dolomite.
Han et al. [10] described five major faults in the Nanmushu deposit. The $\mathrm{F}_{1}$ separated the Dengying Formation and the Huodiya Group with strikes $150^{\circ}$ to $165^{\circ}$ and dips $20^{\circ}$ to $50^{\circ}$. The $F_{2}$ separated upper member of Dengying Formation into two parts, that is, $\mathrm{Z}_{2} d n_{2}{ }^{2}$ and $\mathrm{Z}_{2} d n_{2}{ }^{3}$. This fault is 8 to $15 \mathrm{~m}$ wide with strikes $155^{\circ}$ to $165^{\circ}$ and dips $15^{\circ}$ to $55^{\circ}$. The $\mathrm{F}_{3}$ is the ore-controlling fault in the mining district, which crosscuts the Dengying Formation dolomites and generally parallels to $\mathrm{F}_{2}$. The $\mathrm{F}_{3}$ fault is a thrust fault with strikes $150^{\circ}$ to $165^{\circ}$ and dips $25^{\circ}$ to $55^{\circ}$. This fault is marked by a 3 to $30 \mathrm{~m}$ wide fracture and breccia zone which probably acted as conduits for ore-forming hydrothermal fluids and closely related to the mineralization. The $\mathrm{F}_{4}$ and $\mathrm{F}_{5}$ are postore faults that cut the orebodies.

In the Nanmushu deposit, there are five zinc orebodies and three lead-zinc orebodies (Figure 2; Table 1). Five zinc orebodies occur within $\mathrm{Z}_{2} \mathrm{dn}_{2}{ }^{3}$ of Dengying Formation, of which single orebody is $100-2560 \mathrm{~m}$ in length and $0.5-32.5 \mathrm{~m}$ in thickness, with zinc grades at $1.3-13.1 \mathrm{wt} . \%$. Three lead-zinc orebodies are $86-160 \mathrm{~m}$ in length and $0.8-8.4 \mathrm{~m}$ in thickness, with zinc grades at 1.1-6.4 wt.\% and 0.9-3.3 wt.\%, respectively (Table 1).

Mineralization throughout the Nanmshu $\mathrm{Zn}-\mathrm{Pb}$ deposit is characterized by open space filling and occurs as breccias, veins, stockworks, and massive ores, which appear to be 
TABLE 1: Main characteristics of orebodies in the Nanmushu Zn-Pb deposit.

\begin{tabular}{|c|c|c|c|c|c|c|c|}
\hline \multirow{2}{*}{ Number } & \multirow{2}{*}{ Length (m) } & \multicolumn{2}{|c|}{ Thickness (m) } & \multicolumn{2}{|c|}{ Zn grade (wt.\%) } & \multicolumn{2}{|c|}{$\mathrm{Pb}$ grade (wt.\%) } \\
\hline & & Range & Average & Range & Average & Range & Average \\
\hline Zn1 & 2560 & $1.5 \sim 32.5$ & 7.6 & $1.5 \sim 11.4$ & 4.5 & & \\
\hline $\mathrm{Zn} 2$ & 180 & $1.0 \sim 5.3$ & 2.8 & $1.3 \sim 3.4$ & 2.5 & & \\
\hline $\mathrm{Zn} 3$ & 260 & $0.5 \sim 6.4$ & 2.1 & $2.7 \sim 13.1$ & 4.1 & & \\
\hline $\mathrm{Zn} 4$ & 106 & 1.3 & 1.3 & 1.4 & 1.4 & & \\
\hline Zn5 & 100 & $1.7 \sim 2.5$ & 2.1 & $1.7 \sim 1.9$ & 1.8 & & \\
\hline PbZn1 & 86 & 1.6 & 1.6 & 1.9 & 1.9 & 2.4 & 2.4 \\
\hline $\mathrm{PbZn} 2$ & 160 & $0.8 \sim 8.4$ & 4.6 & $1.1 \sim 3.2$ & 3.0 & 0.9 & 0.9 \\
\hline $\mathrm{PbZn} 3$ & 160 & 5.8 & 5.8 & $1.1 \sim 6.4$ & 5.3 & 3.3 & 3.3 \\
\hline
\end{tabular}

controlled by the third bed of the Dengying Formation $\left(\mathrm{Z}_{2} d n_{2}{ }^{3}\right)$. It can be considered that the cavity filling was formed mainly by hydrothermal mineralization. Hou et al. $[19,20]$ described the $\mathrm{Zn} 1$ as a major ore shoot, which extends $2560 \mathrm{~m}$ and broadens $1.5-32.5 \mathrm{~m}$ (average thickness at $7.6 \mathrm{~m}$ ), with zinc grade at $1.5-11.4 \mathrm{wt} . \%$ (average value at $4.5 \mathrm{wt} . \%$ ) (Table 1), with the ore shoot occupying a dilational flexure in the $1030 \mathrm{~m}$ height (Figure 3). Hydrothermal alteration in the Nanmushu $\mathrm{Zn}-\mathrm{Pb}$ deposit, comprising silicification and carbonate alteration, is not extensive and it is not closely related to mineralization. The shapes of orebodies are stratiform-like, lenticular, and vein, and majority of them are strata-bounded and controlled by the bedding-parallel fractures.

\section{Samples and Analytical Methods}

Samples were collected from the Nanmushu $\mathrm{Zn}-\mathrm{Pb}$ deposit in the open pit at elevations of $1030 \mathrm{~m}, 1070 \mathrm{~m}$, and $1170 \mathrm{~m}$, respectively. Polished blocks and thin sections were initially examined by reflected and transmitted light microscopy to characterize the mineralogy, textures, and parageneses.

Twenty-nine doubly polished-thin sections $(100 \mu \mathrm{m}$ thick) of quartz, dolomite, barite, calcite, and sphalerite were prepared from representative samples of the three hydrothermal mineralization stages (I, II, and III). Petrographic examination of fluid inclusions was conducted using a Nikon E80I microscope with an ultraviolet (UV) attachment using medium-width bandpass excitation filters $(330-380 \mathrm{~nm})$. Oil-bearing fluid inclusions were identified by their fluorescence under UV excitation. Microthermometric measurements were conducted using a Linkham THMS-600 HeatingFreezing Systems (from $-196^{\circ}$ to $550^{\circ} \mathrm{C}$ ) equipped with a Nikon E80I microscope at China University of Geosciences, Wuhan, China. Thermocouples were calibrated at $-56.6^{\circ} \mathrm{C}$, $0.0^{\circ} \mathrm{C}$, and $374^{\circ} \mathrm{C}$ using synthetic FIs supplied by FLUID INC. The heating/freezing rate is generally $0.2^{\circ}$ to $5^{\circ} \mathrm{C} / \mathrm{min}$, but it was reduced to $<0.2^{\circ} \mathrm{C} / \mathrm{min}$ near the phase transformation. The uncertainties for the measurements are $\pm 0.5^{\circ}, \pm 0.2^{\circ}$, and $\pm 2^{\circ} \mathrm{C}$ for runs in the range of $-120^{\circ}$ to $-70^{\circ} \mathrm{C},-70^{\circ}$ to $+100^{\circ} \mathrm{C}$, and $+100^{\circ}$ to $+600^{\circ} \mathrm{C}$, respectively. Ice-melting temperatures were observed at a heating rate of less than $0.1^{\circ} \mathrm{C} / \mathrm{min}$ and homogenization temperatures at rate of $\leq 1^{\circ} \mathrm{C} / \mathrm{min}$.
Fluid inclusions were carefully observed to identify their genetic and compositional types, vapor-liquid ratios, spatial clustering, and the species. The fluid inclusion petrographic study was based on the concept of fluid inclusion assemblages (FIAs) as described by Goldstein [24]: an approach that places fluid inclusions into assemblages that have been trapped penecontemporaneously. Fluid inclusion data was collected from both primary and pseudosecondary fluid inclusion assemblages, representing fluids trapped during crystal growth. Then, microthermometric data was analyzed from two-three inclusions in each FIA. Phase changes in every FIA generally occurred over $1^{\circ}-5^{\circ} \mathrm{C}$, consistent with petrographic observations that inclusions did not undergo postentrapment modification [25]. Microthermometric analyses were carried out on 258 FIAs, and the results are summarized in Table 2.

After careful examination of their petrography, nine doubly polished-thin sections that have adequate primary fluid inclusions were chosen for Laser Raman spectroscopic analysis (LRSA). LRSA was conducted at the State Key Laboratory of Geological Processes and Mineral Resources (GPMR), China University of Geosciences, Wuhan, China. In order to confirm the volatile species of FIs, representative samples were carried out with a Renishaw 1000 Raman microspectrometer according to the method of Burke [26]. Spectrograph aperture was chosen as $25 \mu \mathrm{m}$ or $50 \mu \mathrm{m}$ pinhole. The spectra were recorded with counting time of $20 \mathrm{~s}$ to $40 \mathrm{~s}$, and they ranged from 50 to $3,800 \mathrm{~cm}^{-1}$.

Six sphalerite samples from the main economic oreforming stage II for conventional sulfur isotopic analyses were collected from different localities, including $1030 \mathrm{~m}$ in height, $1070 \mathrm{~m}$ in height, and $1170 \mathrm{~m}$ in height of the Nanmushu zinc-lead deposit (Table 3). Conventional sulfur isotope analyses of the six samples were carried out at Wuhan Institute of Geology and Mineral Resources, China Geological Survey. These samples were first broken into $0.25-0.5 \mathrm{~mm}$ fragments, handpicked to $>95 \%$ purity under a binocular microscope and cleaned ultrasonically, then crushed to $<200$ mesh, and heated under vacuum condition with $\mathrm{Cu}_{2} \mathrm{O}$. The $\mathrm{SO}_{2}$ gas was generated by the oxidation reaction and sulfur isotopic compositions are measured on a MAT-251 gas mass spectrometer. The results are reported as $\delta^{34} \mathrm{~S}$ values with an analytical uncertainty of $0.2 \%$ o $(2 \sigma)$. Sulfur isotopic compositions are reported in comparison with V-CDT. 

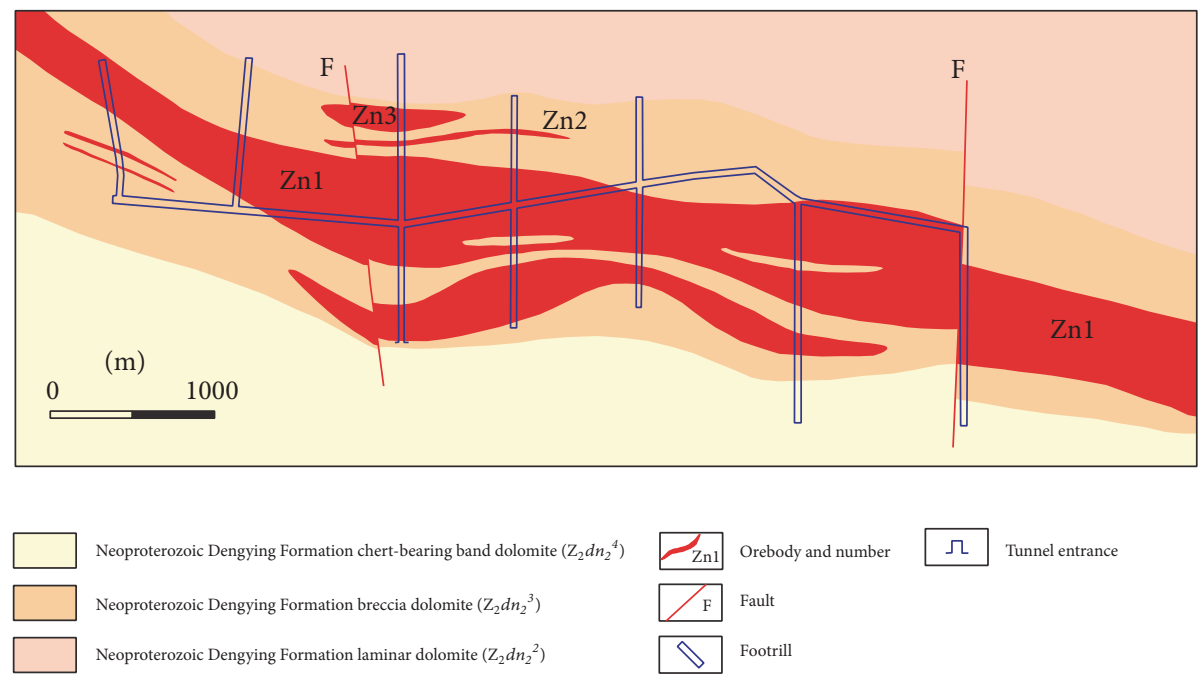

(a)
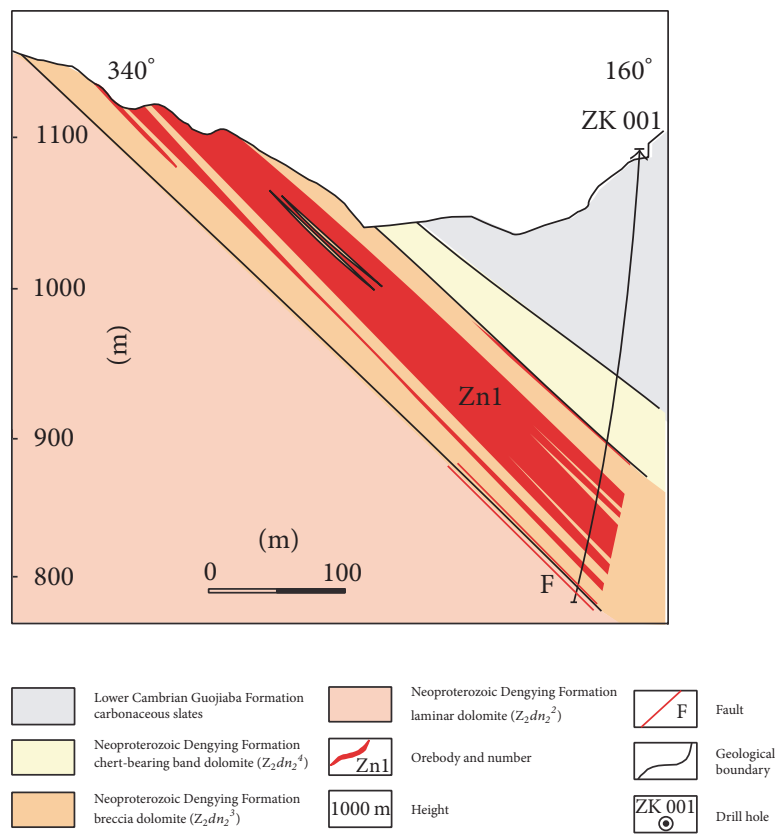

(b)

FIGURE 3: (a) Representative simplified geologic map showing the occurrence and morphology of major orebody $\mathrm{Znl}$ at $1030 \mathrm{~m}$ above sea level in the Nanmushu Zn-Pb deposit (after Li et al., 2007 [9]). (b) Cross-section of the Nanmushu Zn-Pb deposit (modified from Hou et al., 2007 [23]).

\section{Results}

4.1. Paragenetic Mineralization Stages. According to the mineral assemblages and the cross-cutting relationships of the orebodies, three mineralization stages are identified, including the sedimentary diagenetic stage, the hydrothermal ore-forming stage, and the post-ore supergene stage. In the sedimentary diagenetic stage, vein-type bitumen occurs parallel to the country rock beddings or fractures and far away from the orebodies (Figure 4(a)). The fine-grained euhedral pyrite $\mathrm{Py}(\mathrm{s})$ of this stage is 10 to $50 \mu \mathrm{m}$ in size and is disseminated within dolomite with the hydrothermal minerals filling interspace (Figure 4(b)). The hydrothermal ore-forming stage can be subdivided into three substages.

Stage I. Stage I characterized by the assemblage of dolomite + quartz + pyrite + sphalerite + pyrrhotite without galena (Figure 4(c)). This type mineral assemblage usually fills breccias and open spaces with sphalerite impregnation. In this stage, medium-grained pyrite $\mathrm{Py}(\mathrm{a})$ and mediumgrained sphalerite $\mathrm{Sp}(\mathrm{a})$ vary in size ranging from 30 to $100 \mu \mathrm{m}$ and 30 to $200 \mu \mathrm{m}$ in diameter, respectively. Minor inclusions of pyrrhotite are common within the euhedral Py(a). 


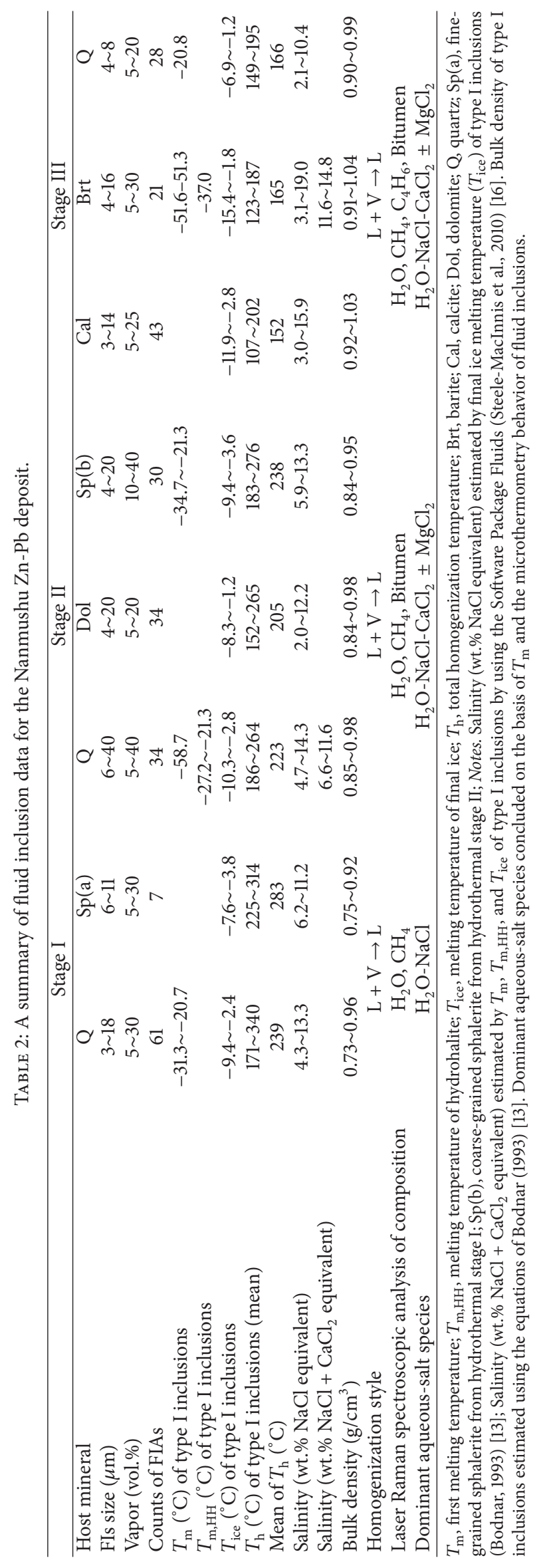


TABLE 3: Sulfur isotopic data of sulfides and sulfate from the Mayuan district.

\begin{tabular}{|c|c|c|c|c|}
\hline Sample ID & Location & Mineral & $\delta^{34} \mathrm{~S}(\% 0)$ & Data source \\
\hline NMS-1170-14 & Nanmushu & Sphalerite & +18.3 & This study \\
\hline NMS-1030-2 & Nanmushu & Sphalerite & +17.4 & This study \\
\hline NMS-1170-13 & Nanmushu & Sphalerite & +18.0 & This study \\
\hline NMS-1070-13 & Nanmushu & Sphalerite & +17.6 & This study \\
\hline NMS-1030-3 & Nanmushu & Sphalerite & +17.4 & This study \\
\hline NMS-1070-2 & Nanmushu & Sphalerite & +17.8 & This study \\
\hline MAYN-1 & Nanmushu & Sphalerite & +18.9 & Li et al., 2007 [9] \\
\hline MAYN-2 & Nanmushu & Sphalerite & +17.7 & Li et al., 2007 [9] \\
\hline MAYN-3 & Nanmushu & Sphalerite & +17.7 & Li et al., 2007 [9] \\
\hline MAYN-4 & Nanmushu & Sphalerite & +18.5 & Li et al., 2007 [9] \\
\hline MAYN-5 & Nanmushu & Sphalerite & +18.1 & Li et al., 2007 [9] \\
\hline MAYN-6 & Nanmushu & Sphalerite & +18.5 & Li et al., 2007 [9] \\
\hline MAYN-7 & Nanmushu & Sphalerite & +19.4 & Li et al., 2007 [9] \\
\hline MY-8 & Nanmushu & Sphalerite & +17.0 & Wang et al., 2008 [7] \\
\hline S-1 & Nanmushu & Sphalerite & +17.8 & Wang et al., 2008 [7] \\
\hline S-2 & Nanmushu & Sphalerite & +18.0 & Wang et al., 2008 [7] \\
\hline MWT1 & Nanmushu & Sphalerite & +18.2 & Hou et al., 2007 [17] \\
\hline MWT3 & Nanmushu & Sphalerite & +17.9 & Hou et al., 2007 [17] \\
\hline H-1 & Nanmushu & Pyrite & +18.8 & Wang et al., 2008 [7] \\
\hline $\mathrm{H}-2$ & Nanmushu & Pyrite & +18.6 & Wang et al., 2008 [7] \\
\hline F-1 & Nanmushu & Galena & +16.8 & Wang et al., 2008 [7] \\
\hline $\mathrm{F}-2$ & Nanmushu & Galena & +16.6 & Wang et al., 2008 [7] \\
\hline F-3 & Nanmushu & Galena & +15.6 & Wang et al., 2008 [7] \\
\hline MWT2 & Nanmushu & Barite & +32.2 & Hou et al., 2007 [17] \\
\hline MWT5-1 & Zhujiahe & Barite & +33.3 & Hou et al., 2007 [17] \\
\hline MWT5-2 & Zhujiahe & Barite & +33.5 & Hou et al., 2007 [17] \\
\hline KXG-9 & Kongxigou & Sphalerite & +16.0 & Wang et al., 2008 [7] \\
\hline MWT4 & Nan'anshan & Galena & +12.9 & Hou et al., 2007 [17] \\
\hline
\end{tabular}

Note. Nanmushu and Kongxigou deposits are from South ore zone of Mayuan district, and Zhujiahe and Nananshan are ore deposits (spots) from Middle ore zone of Mayuan district.

Stage II. Stage II is dominated by the widespread coarsegrained sphalerite $\mathrm{Sp}(\mathrm{b})$ and galena, as well as minor amount of coarse-grained pyrite $\mathrm{Py}(\mathrm{b})$. $\mathrm{Zn}-\mathrm{Pb}$ mineralization starts at stage I and continues with sphalerite impregnation, followed by galena + sphalerite impregnation which subordinate stage II. The cross-cutting relationships of stage I and stage II are observed and shown in Figure 4(d). Stage II is the major mineralization stage for zinc and lead. This mineralization stage is most important in terms of tonnage and mining. Major types of ores include breccia-type, vein-type (Figure 4(d)), and high-grade massive sulfide type (Figure 4(e)), with a simple mineralogy dominated by sphalerite, galena, and pyrite in this stage. Bitumen Bit(a) can also be observed in this stage (Figure 4(f)), occurring in vein-type and breccia-type ores and usually associating with contemporary sphalerite and galena and gangue minerals, such as dolomite, calcite, and quartz. The $\mathrm{Py}(\mathrm{b})$ in this stage surrounded the $\mathrm{Sp}(\mathrm{b})$ or filled the fractures of $S p(b)$ and galena grains (Figure $4(\mathrm{~g})$ ), indicating a relatively late timing of formation.

Stage III. Stage III marked the end of hydrothermal oreforming epoch and was characterized by quartz + barite + calcite + bitumen. Abundant bitumens Bit(b) in this stage are emulsion drops filling the open interspace between other gangue minerals and concentrated along crystal interface of gangue minerals as well as microfissuring or pores (Figures $4(\mathrm{~h})$ and $4(\mathrm{i})$ ), implying the bitumen might have formed a little later than the gangue minerals.

In the supergene stage, oxide minerals include smithsonite, cerusite, and limonite. A paragenetic sequence for minerals in the Nanmushu $\mathrm{Zn}-\mathrm{Pb}$ deposit is summarized in Figure 5.

4.2. Fluid Inclusions Petrography and Laser Raman Spectroscopic Analysis. Samples of sphalerite ( $\mathrm{Sp}(\mathrm{a})$ and $\mathrm{Sp}(\mathrm{b})$ ), dolomite, quartz, calcite, and barite were selected from three hydrothermal stages in the Nanmushu deposit to determine the nature of the fluids associated with mineralization. Abundant primary, pseudosecondary, and secondary FIs in these minerals are found. In order to avoid erroneous interpretations, secondary FIs and/or FIs, which partially decrepitate during the microthermometric processes, were not documented during experiment. FIs were studied in samples that are characterized with absence of plentiful 


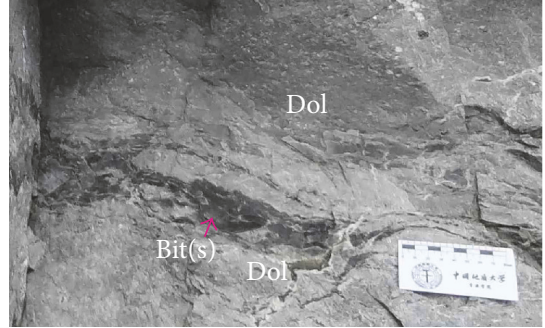

(a)

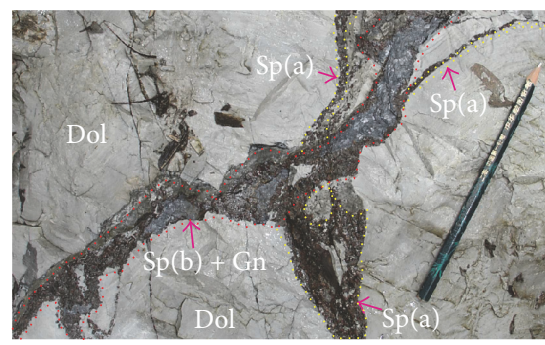

(d)

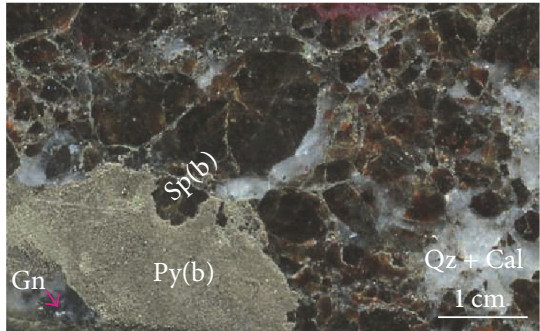

(g)

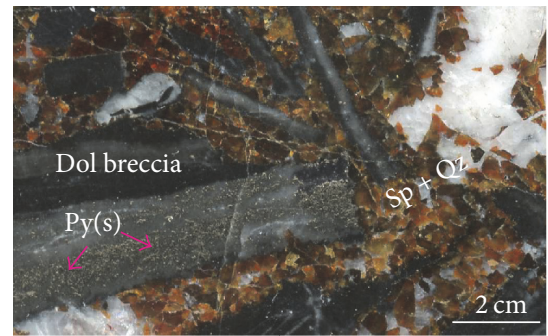

(b)

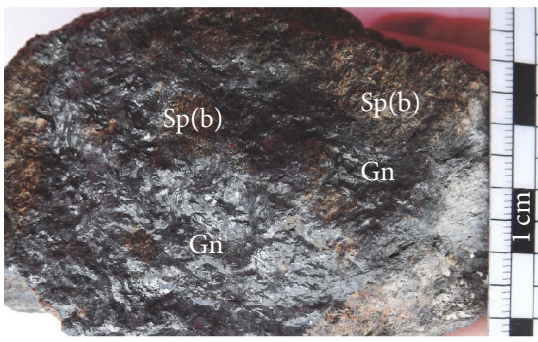

(e)

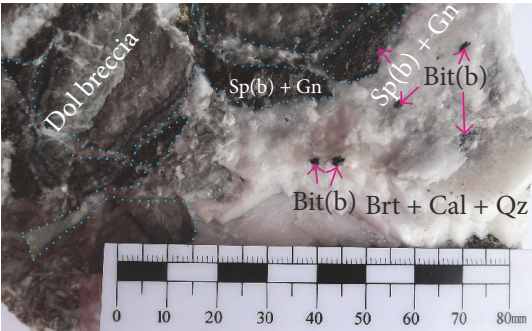

(h)

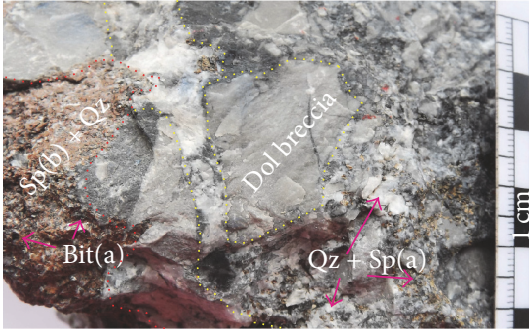

(c)

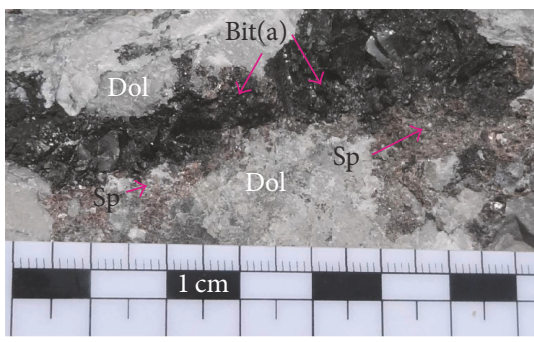

(f)

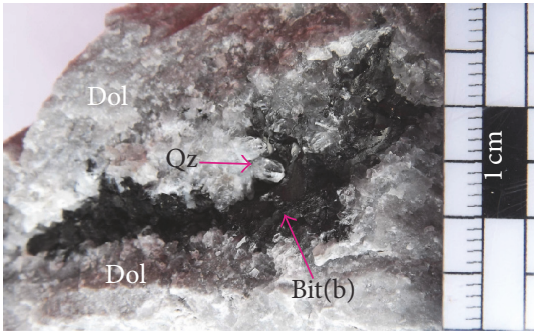

(i)

Figure 4: Photographs of mineralization characteristics of the Nanmushu Zn-Pb deposit. (a) Vein-type bitumen (Bit(s)) occurs parallel to the country rock. (b) Breccia-type ore, dolomite breccia with Py(s) cemented by later hydrothermal mineral. (c) Breccia-type ore, yellow sphalerite + quartz (stage I) and brown sphalerite + quartz (stage II) are cemented by the dolomite breccia. (d) Vein-type ore, assemblages of coarse-grained galena with minor sphalerite as a vein (stage II) crosscut the early sphalerite vein (stage I). (e) High-grade massive ore, assemblages of coarse-grained galena and sphalerite (stage II). (f) Bit(a) associating with contemporary sphalerite occurs in vein (stage II). (g) Later Py(b) surround the early $S p(b)$ in stage II. (h) Sphalerite and galena as breccia (stage II), cemented by late barite + calcite + quartz + bitumen (stage III). (i) Abundant Bit(b) filled in the interspace of quartz in stage III. Bit, bitumen; Brt, barite; Cal, calcite; Dol, dolomite; Gn, galena; Py, pyrite; Qz, quartz; Sp, sphalerite.

\begin{tabular}{|c|c|c|c|c|c|}
\hline \multirow[b]{2}{*}{ Mineral } & \multirow{2}{*}{$\begin{array}{c}\text { Sedimentary } \\
\text { diagenetic } \\
\text { epoch }\end{array}$} & \multicolumn{3}{|c|}{ Hydrothermal epoch } & \multirow{2}{*}{$\begin{array}{c}\text { Supergene } \\
\text { epoch }\end{array}$} \\
\hline & & Stage I & Stage II & Stage III & \\
\hline Dolomite & & & - & - & \\
\hline Quartz & & & & & \\
\hline Pyrite & & & & & \\
\hline Pyrrhotite & & & & & \\
\hline Sphalerite & & & & & \\
\hline Galena & & & & & \\
\hline Bitumen & & & & & \\
\hline Calcite & & & & & \\
\hline Barite & & & & & \\
\hline Smithsonite & & & & & \\
\hline Limonite & & & & & \\
\hline Cerusite & & & & & \\
\hline
\end{tabular}

Figure 5: Paragenetic sequence for minerals in the Nanmushu Zn-Pb deposit. Stage II is the main economic stage with abundant sphalerite and galena. 


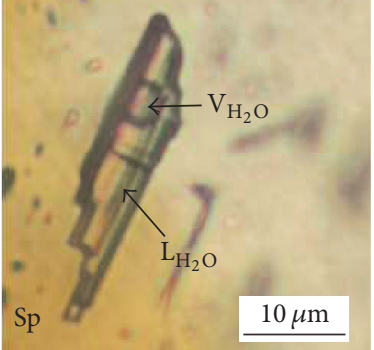

(a)

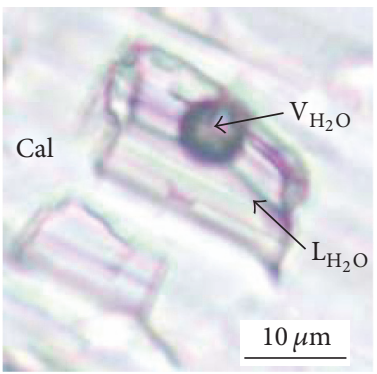

(c)

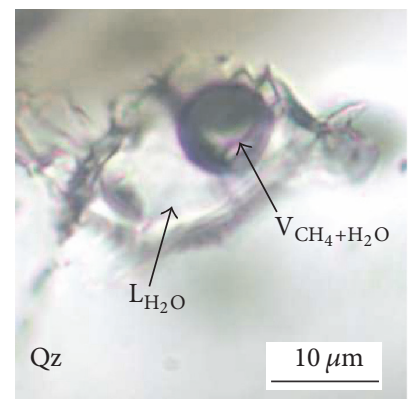

(d)

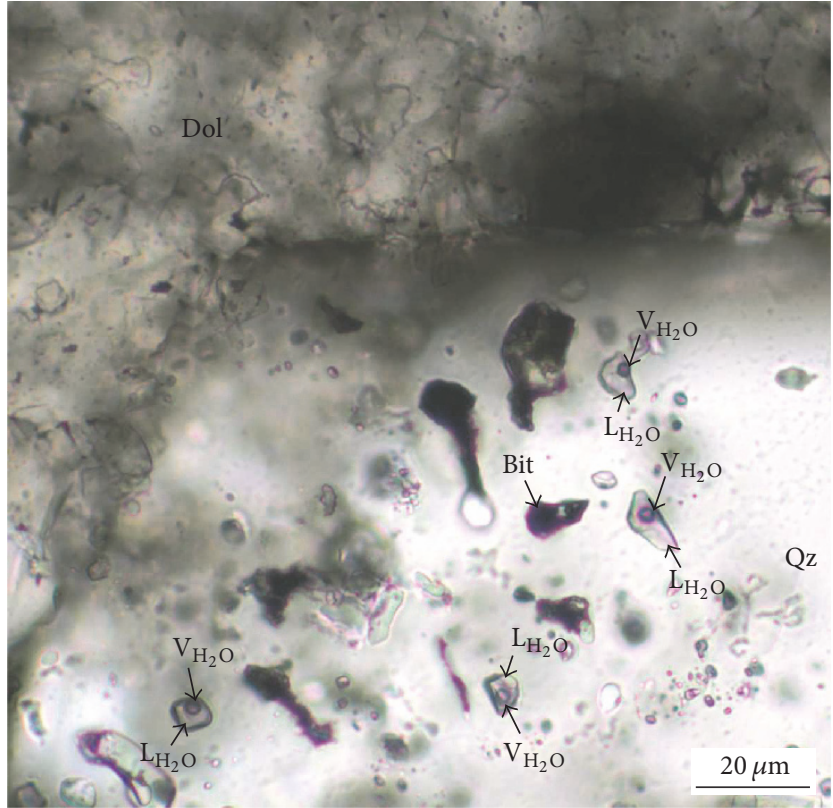

(b)

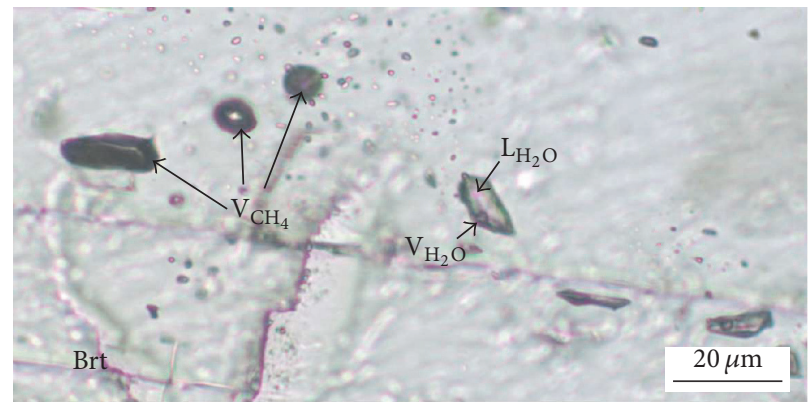

(e)

Figure 6: Photomicrographs of typical FIs hosted in different minerals of the Nanmushu Zn-Pb deposit, under transmitted light, crossednicols. (a) A brown grain sphalerite contains abundant FIs, including one relatively large type I FI. (b) In an automorphic quartz grain, there are abundant type I and type II FIs, which contain detectable bitumen. (c) One type I FI with liquid + vapor phase in calcite. (d) One twophase $\mathrm{CH}_{4}$-rich inclusion in quartz is dominated by water with detectable methane. (e) $\mathrm{CH}_{4}$-rich inclusions with dark bubbles are dominated by detectable methane, coexisting with type I FIs in barite. Brt, barite; Cal, calcite; Dol, dolomite; Qz, quartz; Sp, sphalerite.

secondary inclusions trails and exhibit no evidence of postentrapment modification (i.e., stretching, leaking, and necking down; [25]).

The majority of samples are dominated by primary inclusions in terms of volume, although small secondary inclusions are easily observed. Fluid inclusion morphology in the samples studied varies from polyhedral to round, and their sizes are generally ranging from 4 to $20 \mu \mathrm{m}$. At room temperature $\left(20^{\circ} \mathrm{C}\right)$, most of FIs are two-phase (liquid + vapor) (Figure 6). In the order of decreasing abundance, two compositional types of FIs are distinguished.

(1) The first type is aqueous-salt dominant inclusions (type I), which are found in all examined samples. Type I inclusions are about $6-18 \mu \mathrm{m}$ on average but probably up to $40 \mu \mathrm{m}$ in length, and they are negative crystal, ellipsoidal, near-spherical, or irregular in shape (Figures 6(a) and 6(c)).
The inclusions typically consist of liquid water and a waterdominated vapor phase which occupies 5 to 40 vol.\%.

(2) The second type is hydrocarbon-bearing inclusions (type II), which include three-phase hydrocarbon-bearing inclusions (liquid + vapor + solid phase with bitumen, e.g., Figure 6(b)), two phases' $\mathrm{CH}_{4}$-rich inclusions (Figure 6(d)), one-phase $\mathrm{CH}_{4}$-rich inclusions (Figure 6(e)), and two phases' oil-bearing inclusions (Figure 7). They are of ellipsoidal, near-spherical, or irregular shapes and on average about 6-25 $\mu \mathrm{m}$ in size. The inclusions typically have very consistent aqueous to carbonic phase ratios, and fluorescent oil phase was concentrated around gas bubbles (Figures 7(a) and 7(c)), displaying consistent fluorescence colors within a particular cluster (Figure 7(f)).

At stage I, we observed abundant type I inclusions in dolomite, $\mathrm{Sp}(\mathrm{a})$, and quartz with size ranging from 3 to $18 \mu \mathrm{m}$. 


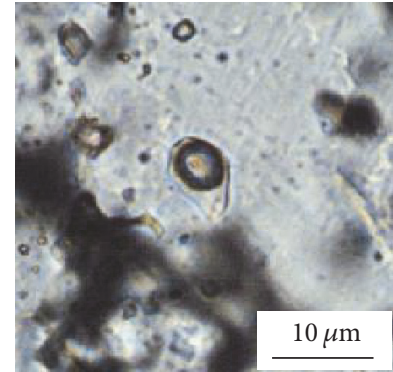

(a)

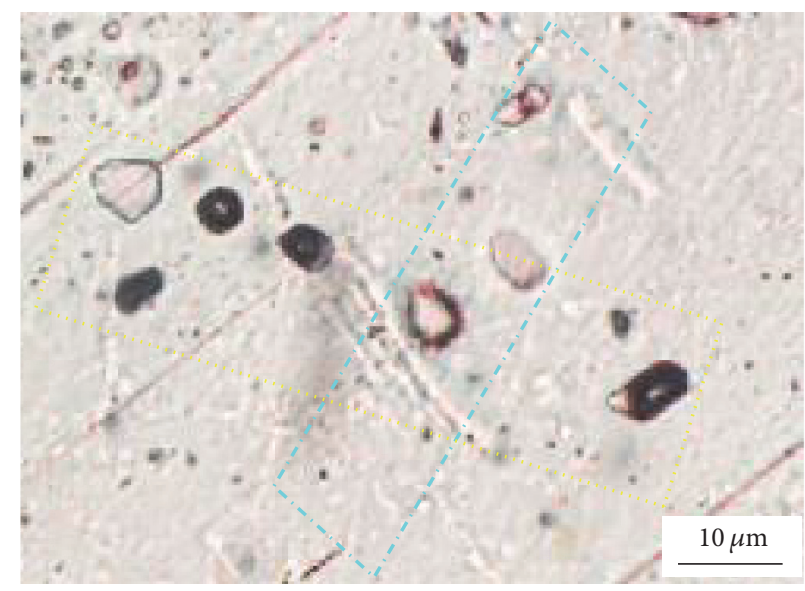

(e)

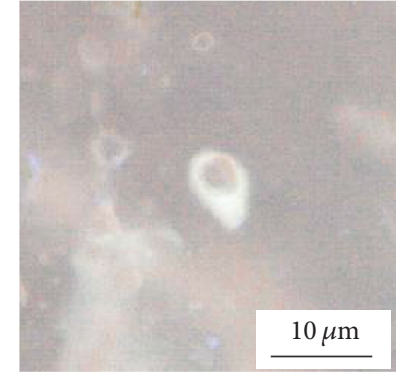

(b)

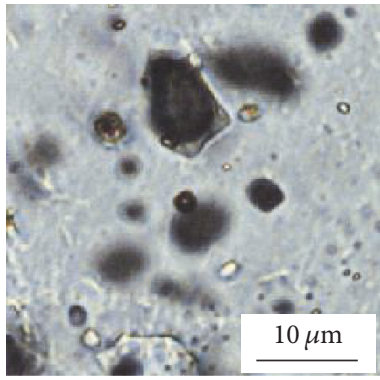

(c)

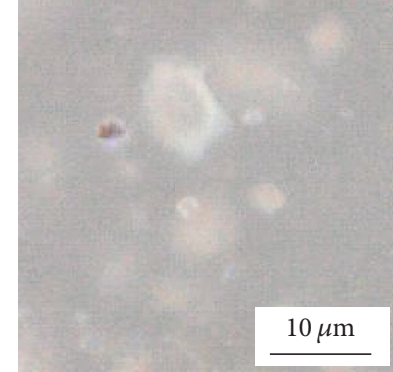

(d)

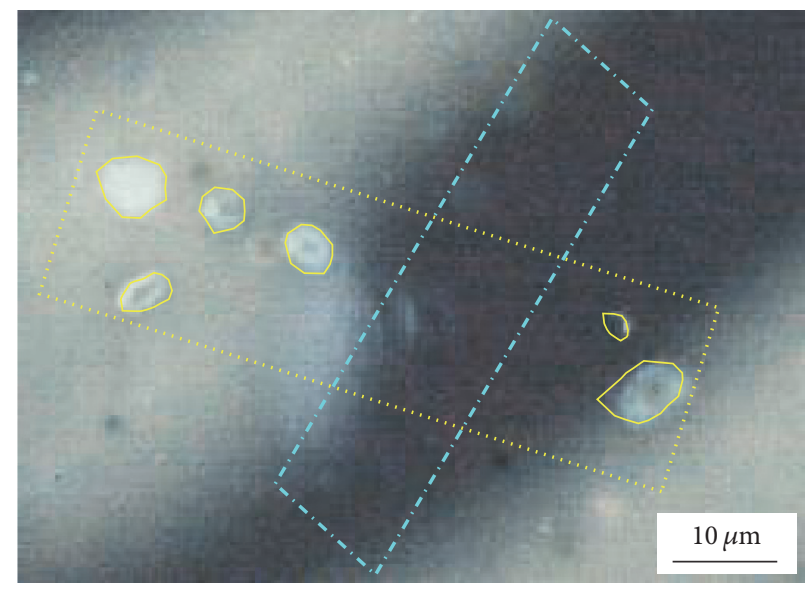

(f)

Figure 7: Photomicrographs of hydrocarbon-bearing inclusions at room temperature $\left(20^{\circ} \mathrm{C}\right)$. ((a), (b)) Liquid-rich oil-bearing inclusion comprises oil and gas. The oil forms a yellow fluorescing. (c) (d) Vapor-rich oil-bearing inclusion contains oil and gas. The oil forms a thin cream fluorescing rim around the hydrocarbon gas bubble. ((e), (f)) A set of oil-bearing inclusions exhibit continuous different filling degrees (in yellow dotted line area) with yellow fluoresces, coexisting with two-phase type I FIs and one-phase $\mathrm{CH}_{4}$-rich inclusions (in blue dash dotted line area). Note: ((a), (c), (e)) under transmitted light, crossed-nicols; ((b), (d), (f)) under UV-epifluorescence.

A smaller number of fluid inclusions contain hydrocarbon (type II) in this stage. Not only $\mathrm{CH}_{4}$-bearing inclusions are observed (determined by Laser Raman spectroscopic analysis) but also oil-bearing inclusions with oil exhibiting a yellow to cream fluorescing rim around the hydrocarbon phase (Figures 7, 8(a), and 8(b)).

At stage II, primary fluid inclusion assemblages occur as clusters of inclusions in gangue minerals, including dolomite, quartz, and coarse-grained $\mathrm{Sp}(\mathrm{b})$ with growth zones. They show regular to negative crystal shape with the size varying from 4 to $40 \mu \mathrm{m}$. Ninety percent of these inclusions are type I. A small number of type II inclusions in sphalerite, containing considerable amounts of $\mathrm{CH}_{4}$ and bitumen, were observed in our study through Laser Raman spectroscopic analysis (Figure 8(c)).

At stage III, type I inclusion occurs in quartz, barite, and calcite with the size varying from 3 to $16 \mu \mathrm{m}$. This stage has more type II inclusions than the two early stages (I and II). There are three-phase hydrocarbon-bearing inclusions (liquid + vapor + solid phase with bitumen), two phases' $\mathrm{CH}_{4}$-rich inclusions, and one-phase $\mathrm{CH}_{4}$-rich inclusions. The compositions of $\mathrm{H}_{2} \mathrm{O}, \mathrm{CH}_{4}, \mathrm{C}_{4} \mathrm{H}_{6}$, and bitumen were detected by Laser Raman spectroscopic analysis (Figures $8(\mathrm{~d})-8(\mathrm{f})$ ).
4.3. Homogenization Temperature and Salinity. The fluid inclusion microthermometry was based on the concept of FIA [24], and microthermometric data were analyzed from two-three inclusions in each FIA. There are aqueoussalt dominant inclusions (type I) and hydrocarbon-bearing inclusions (type II) in the Nanmushu deposit. Figure 9 shows typical FIAs in stages I, II, and III. In our study, we attempted measurements of type II inclusions in different stages; however, only a few type II inclusions were measured as a result of difficulties in observing the temperature $\left(T_{\mathrm{h}}\right)$ of phase transition. A limited number of $\mathrm{CH}_{4}$-rich inclusions in quartz were measured for $T_{\mathrm{h}}$. The $\mathrm{CH}_{4}$-rich inclusions in quartz show $T_{\mathrm{h}}$ values from $-139^{\circ} \mathrm{C}$ to $-90^{\circ} \mathrm{C}$ (to liquid). Within individual FIAs, the ranges of $T_{\mathrm{h}}$ are relatively small, for example, $-139^{\circ} \mathrm{C}$ to $-135^{\circ} \mathrm{C},-91^{\circ} \mathrm{C}$ to $-90^{\circ} \mathrm{C}$, and $-118^{\circ} \mathrm{C}$ to $-120^{\circ} \mathrm{C}$. The coexistence of the $\mathrm{CH}_{4}$-rich inclusions with two-phase inclusions in barite suggests fluid immiscibility (Figure 6(e)). The coexistence of gas, gas-aqueous, and liquid-only inclusions in quartz indicates immiscibility and heterogeneous trapping (Figure 9(f)). As for a few twophase inclusions with minor $\mathrm{CH}_{4}$, their homogenization from liquid + vapor phase to liquid phase took place between $142^{\circ}$ and $165^{\circ} \mathrm{C}$. 


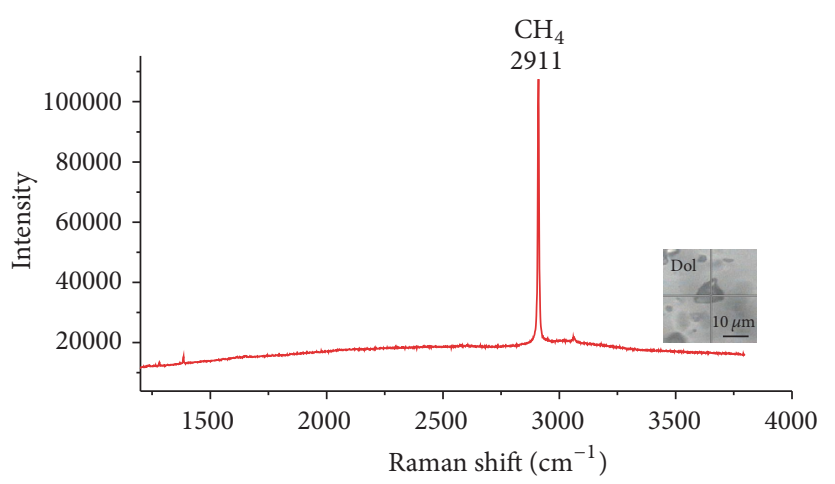

(a)

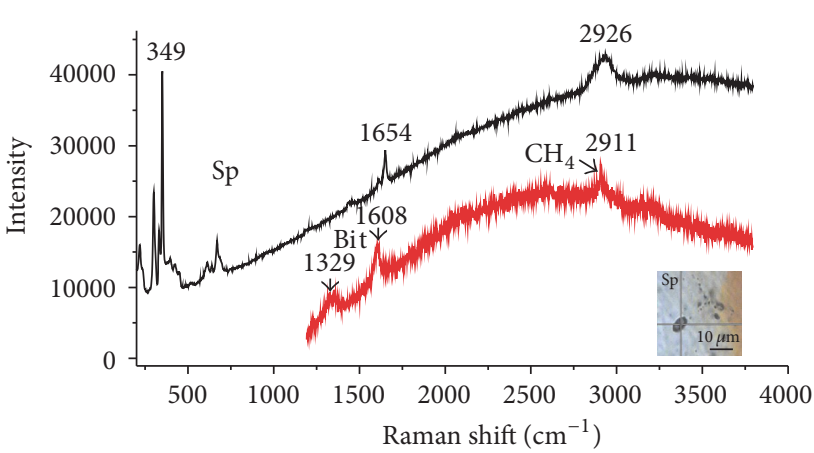

(c)

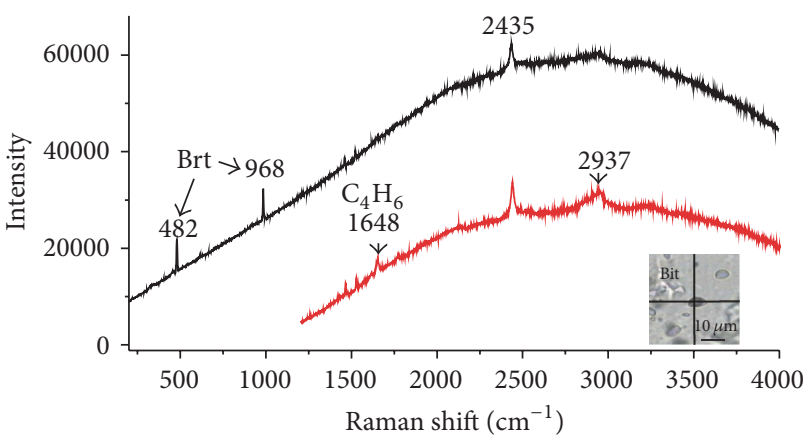

(e)

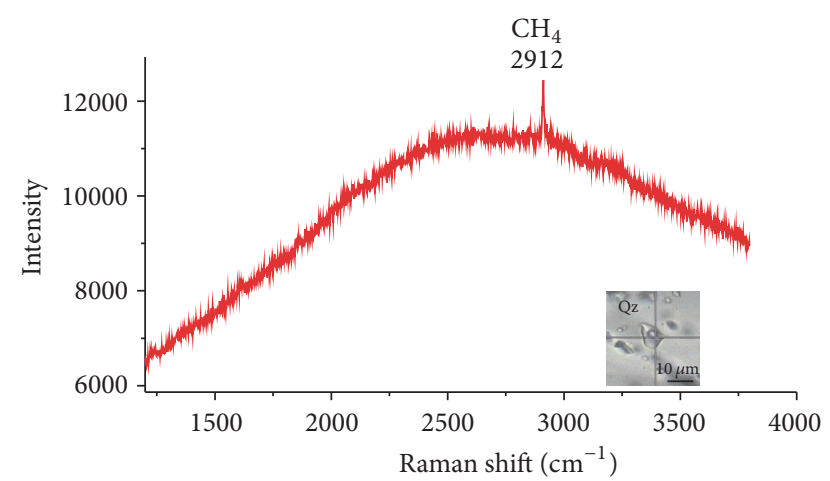

(b)

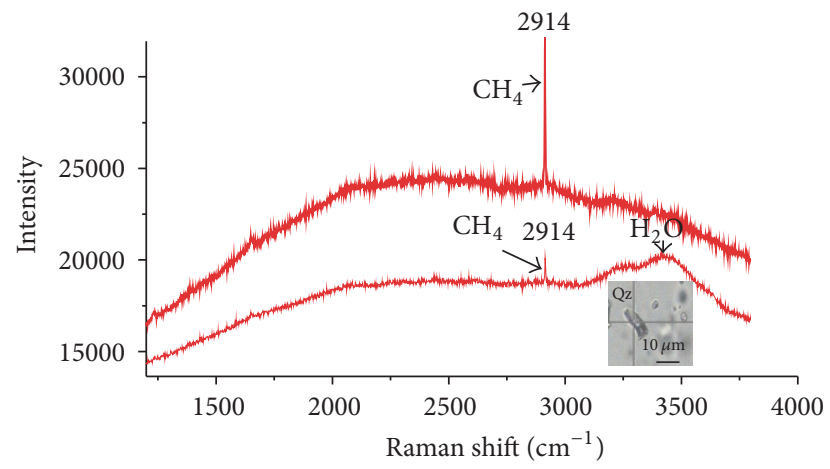

(d)

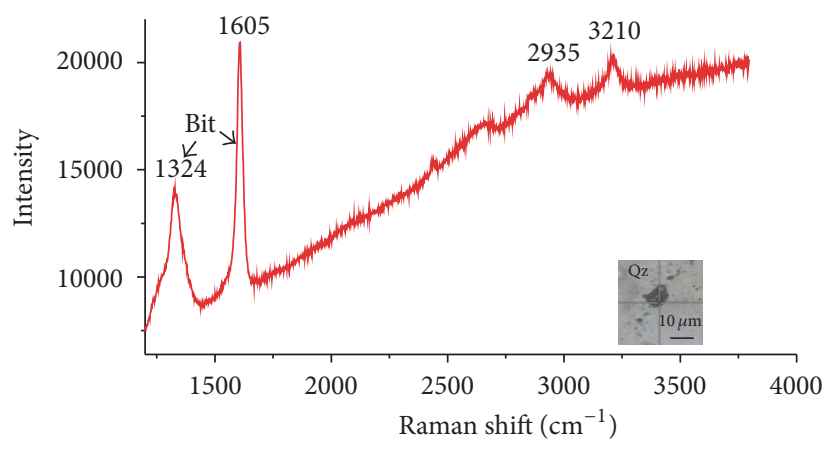

(f)

Figure 8: Representative Raman spectra of hydrocarbon-bearing inclusions for the Nanmushu Zn-Pb deposit. Black line stands for the Raman spectra of hosted minerals, while the red line represents the Raman spectra for FIs. (a) $\mathrm{CH}_{4}$-rich inclusions in dolomite from stage I. (b) $\mathrm{CH}_{4}$-rich inclusions in quartz from stage I. (c) Hydrocarbon-bearing inclusions in sphalerite from stage II, with $\mathrm{CH}_{4}$ and bitumen in the carbonic phase. (d) Hydrocarbon-bearing inclusions in quartz from stage III shows their vapor phase is composed of $\mathrm{CH}_{4}$ with their liquid phase containing $\mathrm{H}_{2} \mathrm{O}$ and $\mathrm{CH}_{4}$. (e) Hydrocarbon-bearing inclusions in barite from stage III, with $\mathrm{C}_{4} \mathrm{H}_{6}$ and bitumen in the carbonic phase. (f) Hydrocarbon-bearing inclusions in quartz from stage III, with bitumen in the carbonic phase. Brt, barite; Dol, dolomite; Qz, quartz; Sp, sphalerite.

Type I inclusion as the predominant type was performed on various minerals from different stages, and microthermometric results are summarized in Table 2 and Figure 10 (stage I, Figures 10(a) and 10(b); stage II, Figures 10(c) and $10(\mathrm{~d})$; stage III, Figures $10(\mathrm{e})$ and $10(\mathrm{f}))$. The first melting temperatures $\left(T_{\mathrm{m}}\right)$, melting temperature of hydrohalite $\left(T_{\mathrm{m}, \mathrm{HH}}\right)$, last ice-melting temperature $\left(T_{\text {ice }}\right)$, and the temperature of total homogenization $\left(T_{\mathrm{h}}\right)$ have been measured in FIs hosted in dolomite, calcite, barite, sphalerite, and quartz. Salinities are calculated as wt.\% $\mathrm{NaCl}$ equivalent using $T_{\text {ice }}$ and the equation of Roedder [12] and wt.\% $\mathrm{NaCl}+\mathrm{CaCl}_{2}$ equivalent using $T_{\mathrm{m}}, T_{\mathrm{m}, \mathrm{HH}}$, and $T_{\text {ice }}$ by using the Software Package Fluids [16]. At stage I, we observed abundant type I inclusions with measurements of homogenization (to liquid phase) temperatures of $171^{\circ}$ to $340^{\circ} \mathrm{C}$ for primary inclusions in quartz and $225^{\circ}$ to $314^{\circ} \mathrm{C}$ for inclusions in $\mathrm{Sp}(\mathrm{a})$, respectively (Table 2). Freezing experiments on type I inclusions in quartz yielded $T_{\mathrm{m}}$ of $-20.7^{\circ} \mathrm{C}$, corresponding to the stable eutectic melting temperature $\left(-20.8^{\circ} \mathrm{C}\right)$ of the $\mathrm{H}_{2} \mathrm{O}-\mathrm{NaCl}$ system (e.g., $[13,15])$. However, one type I inclusion in quartz yielded $T_{\mathrm{m}}$ 


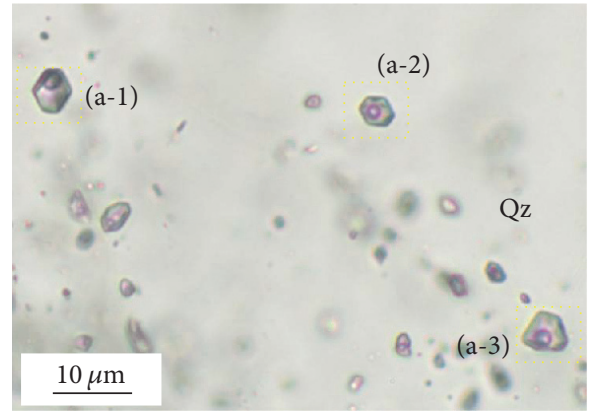

(a)

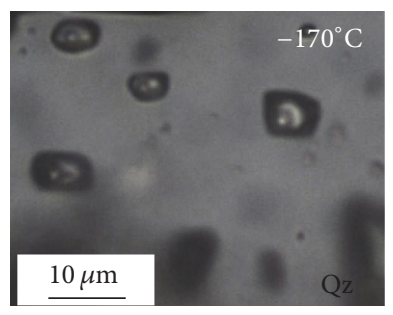

(c)

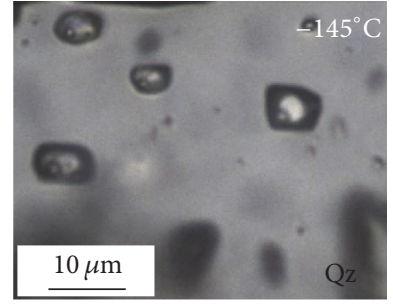

(d)

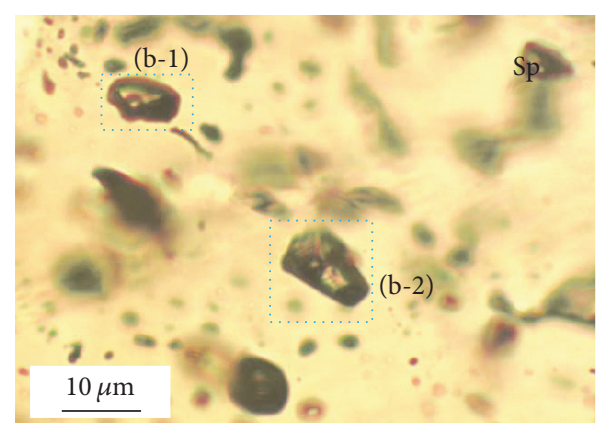

(b)

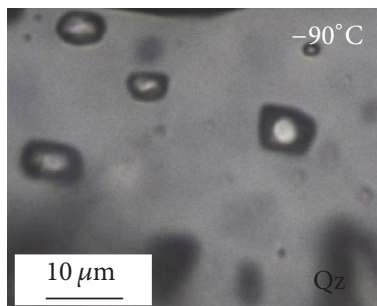

(e)

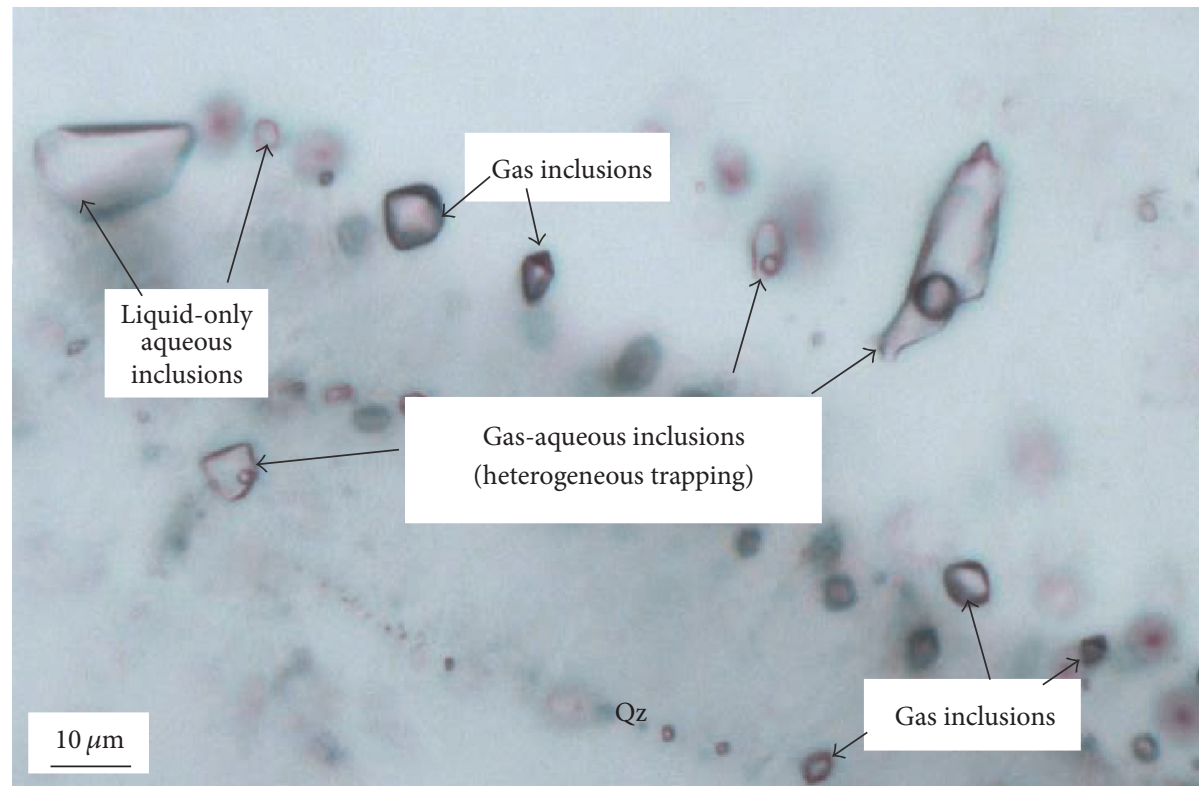

(f)

Figure 9: Photomicrographs showing fluid inclusions assemblages (FIAs) of the Nanmushu Zn-Pb deposit, under transmitted light, crossednicols. (a) In stage I, a trail of two-phase type I FIs (a-1, a-2, and a-3) in the quartz grain, they have consistent vapor/liquid ratios. Microthermometry measurement shows that the ranges of histograms of total homogenization temperatures $\left(T_{\mathrm{h}}\right)$ of this FIA are relatively small, for example, $311^{\circ} \mathrm{C}$ for (a-1), $302^{\circ} \mathrm{C}$ for (a-2), and $308^{\circ} \mathrm{C}$ for (a-3), respectively. They all homogenized to liquid phase. Average temperature $307^{\circ} \mathrm{C}$ as $T_{\mathrm{h}}$ of this FIA recorded in the result. (b) In stage II, a brown grain sphalerite contains two-phase FIs (b-1 and b-2) with consistent vapor/liquid ratios and similar $T_{\mathrm{h}}\left(255^{\circ} \mathrm{C}\right.$ for $(\mathrm{b}-1)$ and $251^{\circ} \mathrm{C}$ for (b-2), resp.). Both of them homogenized to liquid phase. Average temperature $253^{\circ} \mathrm{C}$ of this FIA recorded in the result. ((c), (d), (e)) A trail of $\mathrm{CH}_{4}$-rich inclusions in quartz. When the temperature decreases to $-190^{\circ} \mathrm{C}$, most of one-phase $\mathrm{CH}_{4}$-rich inclusions were frozen. When heated gradually, this type inclusions appeared two-phase $\left((\mathrm{c})\right.$, at $\left.-170^{\circ} \mathrm{C}\right)$, followed by the bubbles reduced $\left((\mathrm{d})\right.$, at $\left.-145^{\circ} \mathrm{C}\right)$, and then homogenized to one liquid phase $\left((\mathrm{e}),-90^{\circ} \mathrm{C}\right)$. (f) Coexistence of gas, gas-aqueous, and liquid-only inclusions in quartz indicating immiscibility and heterogeneous trapping; Qz, quartz; Sp, sphalerite. 

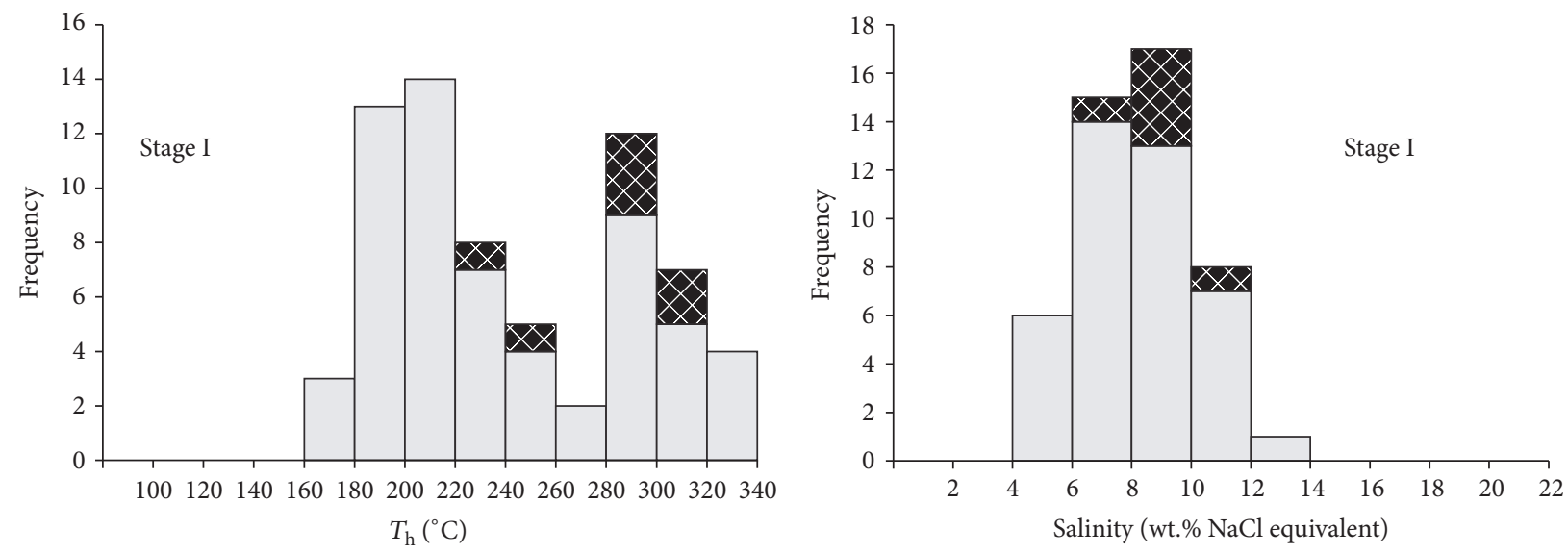

X $\mathrm{Sp}(\mathrm{a}$

Xp(a)

Qz

(a)

(b)
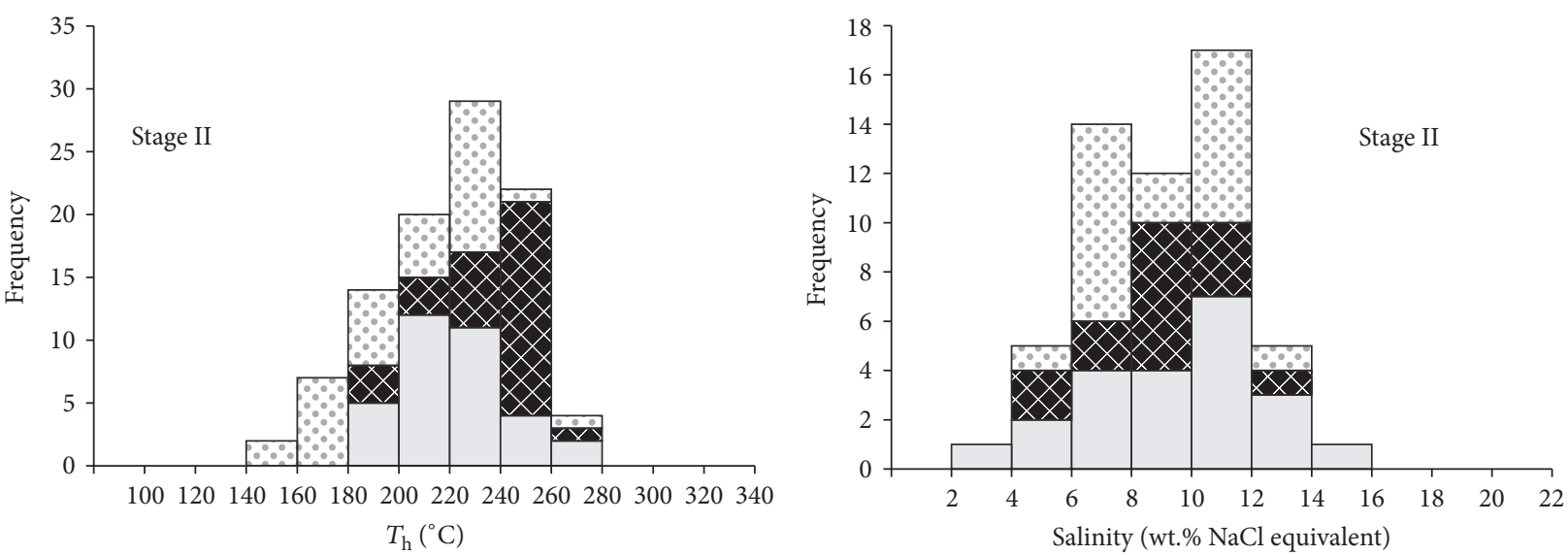

$\begin{array}{ll}\because & \text { Dol } \\ \bigotimes & S p(b)\end{array}$

Qz

(c)

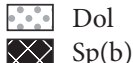

Qz

(d)
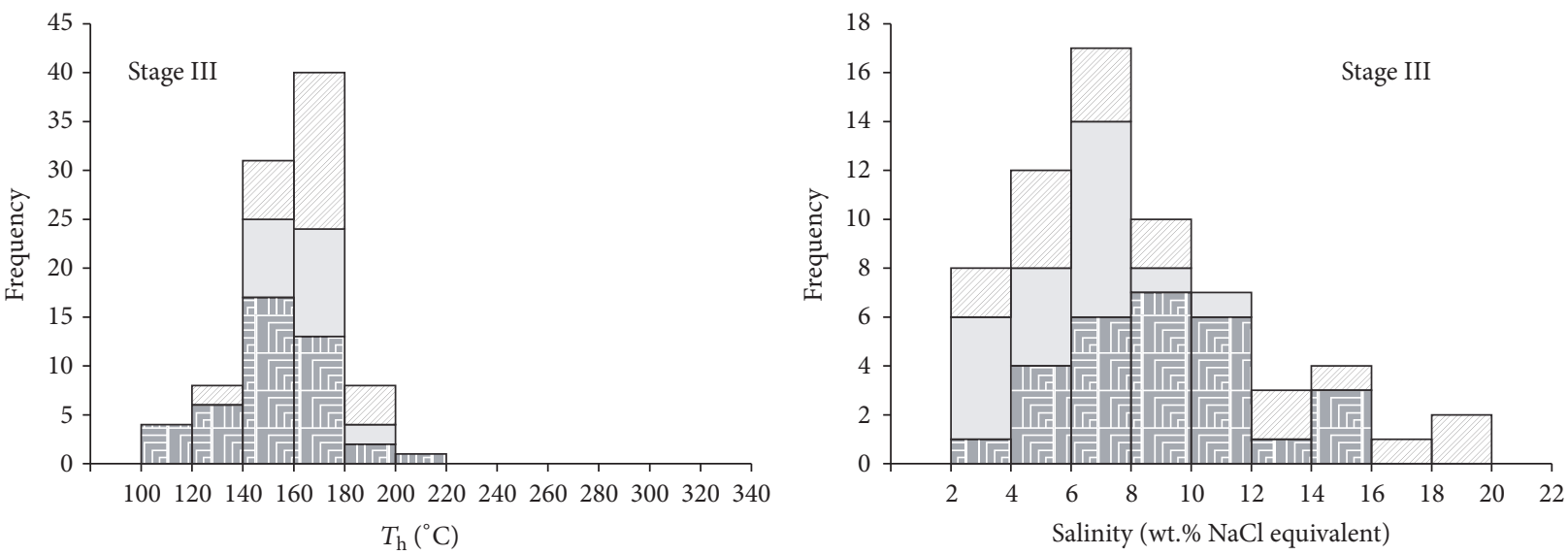

IIㄱ $\mathrm{Cal}$

$\mathrm{Qz}$

$\mathrm{Cal}$

Brt

Qz

(e)

(f)

Figure 10: Histograms of total homogenization temperatures $\left(T_{\mathrm{h}}\right)$ and salinities at different hydrothermal stages in the Nanmushu Zn$\mathrm{Pb}$ deposit. Brt, barite; Cal, calcite; Dol, dolomite; Qz, quartz; Sp(a), fine-grained sphalerite of hydrothermal stage I; Sp(b), coarse-grained sphalerite of hydrothermal stage II. 
of $-31.3^{\circ} \mathrm{C}$, which means it may contain other composition (e.g., $\left.\mathrm{CH}_{4}\right) . T_{\text {ice }}$ occurred between $-9.4^{\circ}$ and $-2.4^{\circ} \mathrm{C}$ in quartz and $-7.8^{\circ}$ and $-3.8^{\circ} \mathrm{C}$ in $\mathrm{Sp}(\mathrm{a})$, corresponding to salinities of $4.0-13.3$ and $6.2-11.2 \mathrm{wt} . \% \mathrm{NaCl}$ equivalent, respectively (Table 2; Figure 10(b)).

At stage II, first melting temperature $\left(T_{\mathrm{m}}\right)$ was observed in a single type I inclusion in quartz at $-58.7^{\circ} \mathrm{C}$, indicating the presence of $\mathrm{CaCl}_{2}$ in addition to $\mathrm{NaCl}$ (e.g., $\left.[12,27]\right) . T_{m}$ of the inclusions in $\mathrm{Sp}(\mathrm{b})$ ranges from $-34.7^{\circ}$ to $-21.3^{\circ} \mathrm{C}$, which are typical characteristics for the $\mathrm{H}_{2} \mathrm{O}-\mathrm{NaCl} \pm \mathrm{CaCl}_{2} \pm \mathrm{MgCl}_{2}$ system $[12,15,27,28]$. When heated gradually, $T_{m}$ was followed by the melting of hydrohalite $\left(T_{\mathrm{m}, \mathrm{HH}}\right)$ and then last ice-melting temperature $\left(T_{\text {ice }}\right)$. We attempted measurements of the temperatures of phase transition of hydrohalite $\left(T_{\mathrm{m}, \mathrm{HH}}\right)$ in each FIA, but it was difficult to observe. Only a few inclusions in quartz observed $T_{\mathrm{m}, \mathrm{HH}}$ values range of $-27.2^{\circ}$ to $-21.3^{\circ} \mathrm{C}$ and $T_{\text {ice }}$ values range of $-7.5^{\circ}$ to $-3.6^{\circ} \mathrm{C}$. Assuming a system of $\mathrm{H}_{2} \mathrm{O}-\mathrm{NaCl}-\mathrm{CaCl}_{2}, \mathrm{NaCl} /\left(\mathrm{NaCl}+\mathrm{CaCl}_{2}\right)$ ratios and compositions in wt. $\% \mathrm{NaCl}+\mathrm{CaCl}_{2}$ equivalent were calculated from $T_{\mathrm{m}, \mathrm{HH}}$ and $T_{\mathrm{m} \text {,ice }}$ using the Software Package Fluids of Steele-MacInnis et al. [16]. The values of $\mathrm{NaCl} /(\mathrm{NaCl}$ $+\mathrm{CaCl}_{2}$ ) ratios range from 0.4 to 1.0 . The salinities are 6.1 to 11.5 wt. $\% \mathrm{NaCl}+\mathrm{CaCl}_{2}$ equivalent, including 4.9-10.4 wt.\% $\mathrm{NaCl}$ equivalent and $0.2-6.5$ wt. $\% \mathrm{CaCl}_{2}$ equivalent.

Fluid inclusions in quartz have $T_{\mathrm{h}}$ values of $186^{\circ}$ to $264^{\circ} \mathrm{C}$ and $T_{\text {ice }}$ values of $-10.3^{\circ}$ to $-2.8^{\circ} \mathrm{C}$, corresponding to salinities of 4.7 to $14.3 \mathrm{wt} . \% \mathrm{NaCl}$ equivalent. Dolomite-hosted fluid inclusions share similar $T_{\mathrm{h}}$ values of $152^{\circ}-265^{\circ} \mathrm{C}$ and $T_{\text {ice }}$ values from $-8.3^{\circ}$ to $-1.2^{\circ} \mathrm{C}$, corresponding to salinities of 5.9 to 13.3 wt. $\% \mathrm{NaCl}$ equivalent. $\mathrm{Sp}(\mathrm{b})$ that is associated with quartz and dolomite has inclusions with Th values of $183^{\circ}$ to $276^{\circ} \mathrm{C}$ and $T_{\text {ice }}$ values of $-9.4^{\circ}$ to $-3.6^{\circ} \mathrm{C}$, corresponding to salinities of 2.0 to $12.2 \mathrm{wt} \% \mathrm{NaCl}$ equivalent (Figures 10 (c) and $10(\mathrm{~d})$ ).

At stage III, fluid inclusions have $T_{\mathrm{h}}$ values of $107^{\circ}$ to $202^{\circ} \mathrm{C}$ and $T_{\text {ice }}$ values of $-15.4^{\circ}$ to $-1.2^{\circ} \mathrm{C}$, corresponding to salinities of 2.1 to $19.0 \mathrm{wt}$.\% $\mathrm{NaCl}$ equivalent (Figures $10(\mathrm{e})$ and $10(\mathrm{f}))$. When the temperature deceases to $-100^{\circ} \mathrm{C}$, the liquid phase of some type I inclusion was yellowish in color, which is characteristic for the eutectic composition of the $\mathrm{H}_{2} \mathrm{O}$ $\mathrm{NaCl}-\mathrm{CaCl}_{2}$ system (e.g., $\left.[4,17]\right)$. The $T_{\mathrm{m}}\left(-51.6^{\circ}\right.$ to $\left.-51.3^{\circ} \mathrm{C}\right)$ and $T_{\mathrm{m}, \mathrm{HH}}\left(-37.0^{\circ} \mathrm{C}\right)$ were observed in barite, supporting the $\mathrm{H}_{2} \mathrm{O}-\mathrm{NaCl}-\mathrm{CaCl}_{2} \pm \mathrm{MgCl}_{2}$ system. Assuming a system of $\mathrm{H}_{2} \mathrm{O}-\mathrm{NaCl}-\mathrm{CaCl}_{2}$, salinities of $11.6-14.8$ wt. $\% \mathrm{NaCl}+\mathrm{CaCl}_{2}$ equivalent were calculated by using the Software Package Fluids [16] based on the values of $T_{\mathrm{m}}, T_{\mathrm{m}, \mathrm{HH}}$, and $T_{\mathrm{m}, \mathrm{ice}}$.

4.4. Sulfur Isotopic Composition. The $\delta^{34} \mathrm{~S}$ values of the analyzed sulfides are summarized in Table 3. Sulfur isotope data in this study were combined with previous published data from the Nanmushu deposit (Figure 11; [7, 9, 17]), and other deposits (e.g., Kongxigou deposit: Wang et al. [7]; Nananshan deposit: Hou et al. [17]) in the Mayuan district. Sulfur isotopic compositions of six sphalerite samples from the same stage II but different locality that was stated above have a narrow $\delta^{34} \mathrm{~S}$ range of +17.4 to $+18.3 \%$, which are similar to those previous data at Nanmushu deposit, between +11.9 and $+23.9 \%$ o $[7,9$, 17] (Table 3). The sphalerite in the Kongxigou deposit shows

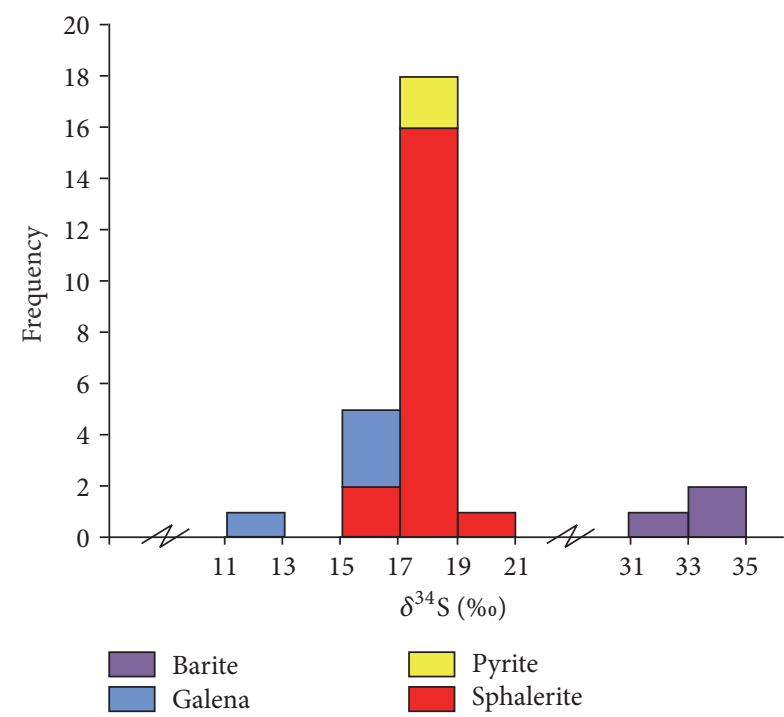

FIGURE 11: Histogram of sulfur isotopic compositions of sulfides and sulfate from the Mayuan district (data sources: Wang et al., 2008 [7]; Li et al., 2007 [9]; Hou et al., 2007 [17]; and this study).

$\delta^{34}$ S value of $+16.0 \%$ [7] and galena in the Nananshan deposit at Mayuan shows $\delta^{34} \mathrm{~S}$ value of $+12.9 \%$ [7]. In addition, barites from the Nanmushu deposit and the Zhujiahe ore prospect have nearly the same $\delta^{34} S$ values of $+32.2 \%$, and +33.3 to $+33.5 \%$, respectively [17] .

\section{Discussion}

5.1. Nature of the Ore-Forming Fluids. Previous published fluid inclusion microthermometric data from the Mayuan district are limited to the work of Hou et al. [17] and Liu et al. [8]. Hou et al. [17] analyzed five samples from Mayuan district, with result of homogenization temperatures ranging from $130^{\circ}$ to $210^{\circ} \mathrm{C}$ but without detailed sample description and fluid inclusion petrography. Liu et al. [8] reported microthermometric measurements only from quartz and calcite, and no data on other minerals, for example, dolomite, barite, and sphalerite. Their results show homogenization temperatures of $98^{\circ}$ to $337^{\circ} \mathrm{C}$ (typically range from $150^{\circ}$ to $300^{\circ} \mathrm{C}$ ) and salinities of 7.7 to $22.2 \mathrm{wt} . \% \mathrm{NaCl}$ equivalent.

In this study, systematic petrographic and microthermometric data have been carried out, and measurements of fluid inclusions in different stages and minerals in the Nanmushu $\mathrm{Zn}-\mathrm{Pb}$ deposit have been presented in Table 2 and Figure 10. Aqueous-salt dominant inclusions (type I) in the Nanmushu deposit illustrate that they contain medium-low temperature $\left(107^{\circ}\right.$ to $\left.340^{\circ} \mathrm{C}\right)$ and medium-high salinity (up to $19 \mathrm{wt} . \%$ $\mathrm{NaCl}$ equivalent) brines (Table 2). Such fluids with this nature are universal in sedimentary basins and are frequently associated with sedimentary hosted $\mathrm{Zn}-\mathrm{Pb}$ deposits (e.g., [14, 29]). In addition, hydrocarbon-bearing inclusions (type II) are easily observed on three hydrothermal stages, occurring as three-phase hydrocarbon-bearing inclusions (liquid + vapor + solid phase with bitumen, e.g., Figure 6(b)), two phases' $\mathrm{CH}_{4}$-rich inclusions (Figure $6(\mathrm{~d})$ ), one-phase $\mathrm{CH}_{4}$ rich inclusions (Figure 6(e)), or two phases' oil-bearing 
inclusions (Figure 7). The similar characteristics are also found in some sedimentary rock hosted $\mathrm{Zn}-\mathrm{Pb}$ deposits which are located in/around sedimentary basins worldwide [29-32]. According to the discussion above and geological location (e.g., near Sichuan Basin) of the Nanmushu Zn-Pb deposit, we propose that the ore-forming fluids are basinal brines. As the features of ore-forming fluids (mediumlow temperature, medium-high salinity with hydrocarbon), brines of sedimentary basins were thought to supply oreforming materials and contribute to the mineralization.

The presence of hydrocarbon-bearing inclusions and bitumen, especially widely distributed $\mathrm{CH}_{4}$-rich inclusions, demonstrates that there were extensive hydrocarbon activities in the Nanmushu deposit. In general, the $\mathrm{CH}_{4}$-rich hydrothermal fluids may come from three ultimate sources: (1) abiogenic origin derived from the mantle [33, 34]; (2) abiogenic origin derived from postmagmatic alteration by Fischer-Tropsch type synthesis [35-37]; (3) incorporation of thermally decomposed organic material (thermogenesis) or/and products from microbial processes (bacteriogenesis) [38-41]. The deposit characteristics (without postmagmatic alteration) and sulfur isotope characteristics excluded the abiogenic origin. LRM results show $\mathrm{CH}_{4}$-bearing fluid inclusions commonly existed in sphalerite, dolomite, quartz, and barite, illustrating that these minerals were precipitated from a common, methane-rich ore-forming fluid. As fluorescence effect of organic materials may mislead the analysis, only $\mathrm{CH}_{4}$ Raman peaks can generally be detected above the high background (Figure 8). In addition, the $\delta^{13} \mathrm{C}$ values for $\mathrm{CH}_{4}$ in fluid inclusions are $-37.2 \%$ and $-28.1 \%$ in quartz and $-21.0 \%$ o to $-23.7 \%$ in barite [8]. These extremely negative $\delta^{13} \mathrm{C}$ values suggest that an isotopically light carbon source contributed to the ore-forming fluids. Thus, the organic origin may be a reasonable mechanism to explain the abundant $\mathrm{CH}_{4}$-rich inclusions.

5.2. Origin of the Sulfur. As many important sulfur reservoirs have distinct sulfur isotopic signature, the $\delta^{34} \mathrm{~S}$ values can be used as representative of the sulfur sources [42]. The $\delta^{34} \mathrm{~S}$ values of the sulfides show a relatively narrow range (Figure 11, Table 3) but significantly different from those of mantle-derived magmatic sulfur (around 0\%; [43]). The $\delta^{34} S$ values of sulfides in the Nanmushu deposit are slightly lower than those of evaporites in the Cambrian to Triassic strata $(+15$ to $+35 \%$; [44]) and the seawater sulfates of the Neoproterozoic Dengying Formation (+20 to $+39 \%$; [45]). However, the $\delta^{34} \mathrm{~S}$ value of barite in the Nanmushu deposit is $32.2 \%$ [17], similar to those of evaporites in the Cambrian to Triassic strata or seawater sulfates of the Neoproterozoic Dengying Formation.

The $\delta^{34} \mathrm{~S}$ values of sulfides from the Nanmushu deposit suggest that the sulfur was likely to be derived from $\mathrm{SO}_{4}{ }^{2-}$ reduction from seawater and/or evaporitic sulfates that have possibly been leached by basinal brines during mineralization. In consideration of temperatures of FIs in the $\mathrm{Sp}(\mathrm{a})$ and $\mathrm{Sp}(\mathrm{b})$ at the range of $183^{\circ}-314^{\circ} \mathrm{C}$, the possible mechanism for reduced sulfur is thermochemical sulfate reduction (TSR), because TSR can occur under high temperatures while bacterial sulfate reduction (BSR) can only take place under low temperatures $\left(<127^{\circ} \mathrm{C}\right)[38,46]$. In addition, TSR would like to produce a series of organic matter (e.g., bitumen, $\mathrm{C}_{3} \mathrm{H}_{8}$, $\mathrm{C}_{2} \mathrm{H}_{6}$, and $\mathrm{CH}_{4}$ ) $[38,40,46,47]$. Ore-forming fluids show an increase in carbonaceous contents over time. In stage I, quartz-hosted fluid inclusions with $\mathrm{CH}_{4}$ in volatile and some oil-bearing inclusions occur. In stage II, $\mathrm{CH}_{4}$-rich inclusions are relatively widespread, which occur not only in gangue minerals but also in sphalerite. Moreover, carbonic phase in sphalerite also includes bitumen. In stage III, the increasing amount and species of hydrocarbon-bearing inclusions (e.g., $\mathrm{CH}_{4}, \mathrm{C}_{4} \mathrm{H}_{6}$, and bitumen) are consistent with changing fluid composition, which is likely caused by TSR during mineralization.

Therefore, it is reasonable to suggest that the positive $\delta^{34} \mathrm{~S}$ values $(+15.6$ to $+19.4 \%$ o) in the Nanmushu $\mathrm{Zn}-\mathrm{Pb}$ deposit were resulted from TSR. This phenomenon agrees well with geologic and FIs characteristics in the Nanmushu deposit, which show occurrence of organic matter including bitumen in mineralization stages (Figure 4) and abundant carbonaceous contents in hydrocarbon-bearing inclusions (Figures 6, 7, and 9). TSR-related chemical reactions may happen $[38,46]$ :

$$
\mathrm{CH}_{4}+\mathrm{SO}_{4}{ }^{2-} \longrightarrow \mathrm{CO}_{3}{ }^{2-}+\mathrm{H}_{2} \mathrm{~S}+2 \mathrm{H}_{2} \mathrm{O}
$$

Hydrocarbons $+\mathrm{CaSO}_{4} \rightarrow$ altered hydrocarbons + solid bitumen $+\mathrm{CaCO}_{3}+\mathrm{H}_{2} \mathrm{~S}+\mathrm{H}_{2} \mathrm{O}$. TSR-related reduced sulfur (e.g., $\mathrm{H}_{2} \mathrm{~S}$ ) could have been involved in the ore-forming process with chemical reactions:

$$
\begin{aligned}
& \mathrm{Zn}^{2+}+\mathrm{H}_{2} \mathrm{~S} \longrightarrow \mathrm{ZnS} \downarrow(\text { sphalerite })+2 \mathrm{H}^{+} ; \\
& \left.\mathrm{Pb}^{2+}+\mathrm{H}_{2} \mathrm{~S} \longrightarrow \mathrm{PbS} \downarrow \text { (galena }\right)+2 \mathrm{H}^{+} .
\end{aligned}
$$

They are responsible for the deposition of sphalerite and galena in the ore-forming processes.

5.3. Evolution of the Ore-Forming Fluids. In the Nanmushu $\mathrm{Zn}-\mathrm{Pb}$ deposit, microthermometry and Laser Raman spectroscopic analyses for fluid inclusions have identified amounts of salts (mainly $\mathrm{NaCl}$ mixed with $\mathrm{CaCl}_{2}$ and $\mathrm{MgCl}_{2}$ ) and carbonaceous contents (mainly $\mathrm{CH}_{4}, \mathrm{C}_{4} \mathrm{H}_{6}$, and bitumen, Figure 8) in fluids. Hydrocarbon-bearing inclusions have changeable liquid/vapor ratios. Oil-bearing inclusions exhibit continuous different filling degrees with yellow fluoresces (Figure 6). They typically occur together with only vapor hydrocarbon phase $\mathrm{CH}_{4}$ inclusions and aqueous-salt inclusions (Figures 6 and 7). The coexistence of gas $\left(\mathrm{CH}_{4}\right)$, gas-aqueous, and liquid-only inclusions was also observed (Figure 9). Such phenomenon provides evidence that the fluid system of the Nanmushu $\mathrm{Zn}-\mathrm{Pb}$ deposit consisted of an aqueous-salt solution and an immiscible hydrocarbon phase (e.g., $[3,4,48]$ ).

Temperatures of FIs exhibit a decreasing trend from stage I to stage III (Table 2, Figures 10 and 12). Salinities of stage I (4.3 to $13.3 \mathrm{wt} . \% \mathrm{NaCl}$ equivalent), stage II $(2.0$ to 14.3 wt.\% $\mathrm{NaCl}$ equivalent), and stage III (2.1 to $19.0 \mathrm{wt} . \%$ $\mathrm{NaCl}$ equivalent) are similar (Figures 10 and 12). Notably, FIs 


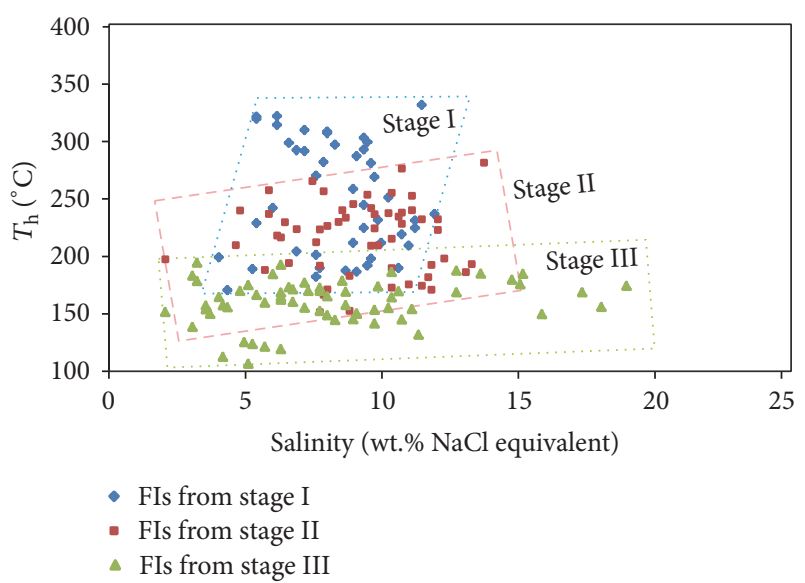

FIGURE 12: Total homogenization temperatures versus salinities diagram for the three hydrothermal stages showing fluid evolution of the Nanmushu $\mathrm{Zn}-\mathrm{Pb}$ deposit.

hosted in the barite which were only found at stage III have the relatively high salinities (up to $19.0 \mathrm{wt} . \% \mathrm{NaCl}$ equivalent, Table 2). On the basis of ore-forming fluids characteristics in the Nanmushu $\mathrm{Zn}-\mathrm{Pb}$ deposit (Figures 10 and 12), the decoupling between the temperature and salinity in fluids may suggest that there was an addition of external fluid with higher salinity (with $\mathrm{CaCl}_{2} \pm \mathrm{MgCl}_{2}$-enriched) flow into the relatively lower salinity primary fluid system during mineralization of this deposit.

In hydrothermal stage I, the original $\mathrm{H}_{2} \mathrm{O}-\mathrm{NaCl}$ fluid with methane enrichment is predominately in the fluid system, with a small quantity of later fluid into the connatural fluid system. Temperature of FIs shows a distinct bimodal with maxima at around $180^{\circ}$ and $300^{\circ} \mathrm{C}$ (Figure $10(\mathrm{a})$ ), probably because of the original fluid and later external fluid with difference temperatures and/or heterogeneous trapping. FIAs with wide ranges of Th values in stage I imply heterogeneous trapping, accompanied by immiscibility of hydrocarbon phase and aqueous-salt solution.

In stage II, with adding an increasing amount of higher salinity $\mathrm{CaCl}_{2} \pm \mathrm{MgCl}_{2}$-rich brine, the temperatures of FIs continuously decreased, and the salinities of the fluid system can reach up to $14.3 \mathrm{wt} . \% \mathrm{NaCl}$ equivalent (Figure 12 and Table 2). $\mathrm{CH}_{4}$-rich inclusions appear not only in gangue minerals but also in sphalerite. Hydrocarbon-bearing inclusions in sphalerite with $\mathrm{CH}_{4}$ and bitumen in the carbonic phase were detected by Laser Raman spectroscopic analysis (Figure 8).

In stage III, owing to the continuous addition of the extraneous fluid, temperature of fluid became lower with its salinities rising inversely (Table 2, Figure 12). Higher number species of $\mathrm{CH}_{4}, \mathrm{C}_{4} \mathrm{H}_{6}$, and bitumen were detected in the carbonic phase of hydrocarbon-bearing inclusions (Figure 8).

The presence of $\mathrm{CH}_{4}$-rich inclusions in each hydrothermal stage (Table 2 and Figure 8) suggests that the original fluids contain abundant hydrocarbons. The hydrocarbons may react with sulfates to produce a series of organic matter through TSR. Thus, ore-forming fluids show an increase in carbonaceous contents and species. It implies that the hydrocarbons were entrained with the hydrothermal fluids throughout the paragenetic sequence during mineralization. Bitumen associated with contemporary sphalerite vein occurs in stage II (Figure 4). In the main stage sphalerite and quartz, primary hydrocarbon-bearing inclusions containing bitumen, also were observed and detected (Figures 4 and 8). These characteristics strongly suggest an intimate relationship between bitumen and mineralization.

Although PVTX modelling and equations of fluid inclusion from simultaneously and homogeneously entrapped FIAs can be used to estimate fluid pressures, when irreversible physical and chemical changes happened, the PVTX modelling and equations are invalid. Based on the foregoing discussion, the fluid system of the Nanmushu $\mathrm{Zn}-\mathrm{Pb}$ deposit is a heterogenous fluid system, which consisted of an aqueous-salt solution and an immiscible hydrocarbon phase. However, TSR is an irreversible process [38]. When solid bitumen as hydrocarbon phase appears in the hydrocarbonbearing inclusions, it implies that irreversible physical and chemical changes happened in the closed system of the hydrocarbon inclusions [15]. Actually, TSR and solid bitumen as hydrocarbon phase in the hydrocarbon-bearing inclusions both exist in the Nanmushu $\mathrm{Zn}-\mathrm{Pb}$ deposit. Taking these into account, it seems there are no appropriate FIAs to calculating pressure on account of complex fluid system in the Nanmushu $\mathrm{Zn}-\mathrm{Pb}$ deposit.

5.4. Genetic Type of the Deposit. Ore genesis of the Nanmushu $\mathrm{Zn}-\mathrm{Pb}$ deposit has been discussed since it was first discovered in 2004. In spite of the orebodies generally controlled by stratum and structure, the occurrence of abundant vein-type and breccia-type ores shows that hydrothermal activity is critical for the mineralization. Ore-forming fluids in the Nanmushu deposit are medium-low temperature $\left(107^{\circ}-340^{\circ} \mathrm{C}\right)$ and medium-high salinity (up to $19 \mathrm{wt} . \% \mathrm{NaCl}$ equivalent) brines with carbonaceous components of $\mathrm{CH}_{4}, \mathrm{C}_{4} \mathrm{H}_{6}$, and bitumen concentrations, similar to those of basinal brine systems with hydrocarbons worldwide [49-51]. Lower Cambrian Guojiaba Formation carbonaceous slate may have acted as a capping aquitard for mineralizing fluids flowing through the more permeable sandstone and dolomite.

The sphalerites from the sediment-hosted $\mathrm{Zn}-\mathrm{Pb}$ ores at the Mayuan district have been dated with a Rb-Sr isochron age of $486 \pm 12 \mathrm{Ma}$ (Ordovician, Li et al. [9]). Recently, Han et al. [10] collected the later hydrothermal bitumen and obtained a bitumen Re-Os isochron age of $128 \pm 8 \mathrm{Ma}$. In this deposit, three generations of bitumen have been observed, including Bit(s), Bit(a), and Bit(b) that have distinctive association of minerals and textures. The Bit(s) formed during sedimentary diagenetic stage, far from the orebody, and they occur parallel to the country rock beddings and fractures. The $\operatorname{Bit}(a)$ formed during mineralization of the main economic stage II. Post-ore Bit(b) formed later than the gangue minerals of stage III or even later than the whole mineralization stages. Based on the sample descriptions of Li et al. [9] and Han et al. [10] and the petrography observations of our study, we regard that ca.486 Ma for sphalerite $(S p(b))$ represents the major mineralization age of stage II and ca.128 Ma for bitumen (Bit(b)) formed during post-ore stage. Both of them 
are much younger than the sedimentation age of the host Neoproterozoic Dengying Formation ( 540 Ma, [52]). The mineralization of the Nanmushu deposit, located in the northern Yangtze Block, may have lasted for a prolonged period. The obtained ages fall in the range between Caledonian orogeny and Indosinian-Yanshanian movement, which both have been regarded as the two main mineralization events in the Yangtze Block. Compaction and topographically driven fluid flows are the likely mechanisms in the Nanmushu $\mathrm{Zn}-\mathrm{Pb}$ deposit. Sediment compaction probably occurred during the Neoproterozoic to Permian that caused thick cover sequence (over $9 \mathrm{~km}$ ) and major sedimentation in the basin, while the basin compression and topographic relief occurred during the Indosinian-Yanshanian movement. The foreland basin system of the northern Yangtze plate records the intracontinental tectonic deformation and oblique amalgamation of the Yangtze and North China-Qinling-Dabie complex plates during the late Triassic (late Indosinian) to probably early Jurassic (early Yanshanian) [53]. The northern Sichuan basins were filled by the depositional system and the Micangshan fold-and-thrust belt belonged to the foreland belt. It is noted that the Nanmushu $\mathrm{Zn}-\mathrm{Pb}$ deposit occurs near northern Sichuan Basin and the Micangshan fold-and-thrust belt. Therefore, the aforementioned tectonic movement could have driven the large-scale flow of basinal brines carrying ore-forming metals to migrate a long distance, which was in response to the Nanmushu $\mathrm{Zn}-\mathrm{Pb}$ deposit mineralization.

In the Sichuan basins, the $\mathrm{Pb}-\mathrm{Zn}$ deposits and paleo-oilgas reservoirs show a closed spatial distribution and they are possibly controlled by the basinal fluid flow [47, 54]. The compressional tectonic event may influence the Chipu $\mathrm{Pb}$ $\mathrm{Zn}$ deposit and the gas reservoir hosted in the Dengying Formation may contribute to mineralization [54]. It is noted that the Chipu $\mathrm{Pb}-\mathrm{Zn}$ deposit has abundant organic matter and is hosted within the Dengying Formation, similar to the Namushu $\mathrm{Zn}-\mathrm{Pb}$ deposit. We speculate organic matter in the Namushu $\mathrm{Zn}-\mathrm{Pb}$ deposit possibly came from a paleooil-gas reservoir on and/or near the sites of the Nanmushu $\mathrm{Zn}-\mathrm{Pb}$ deposit. Given geological, geochemical, and fluid inclusion characteristics mentioned above for the Nanmushu $\mathrm{Zn}-\mathrm{Pb}$ deposit, it is consistent with typical MVT deposits. They are epigenetic deposits, which are hosted in carbonatedominated sedimentary rocks, generally stratabound and stratiform with sulfide minerals replacing carbonates and filling open spaces in the host rocks $[29,55]$. Most of the world's MVT Zn-Pb deposits occur in orogenic forelands and mineralizations are accompanied by tectonic movement $[29,56]$. In addition, many of typical MVT deposits have low-moderate temperatures and medium salinities of basinal brines with abundant hydrocarbons [29], which are consistent with the Nanmushu deposit studied here. Therefore, we suggest that the Nanmushu deposit is a MVT Zn-Pb deposit.

\section{Conclusions}

The Nanmushu deposit is a MVT Zn-Pb deposit, and the mineralization contains three stages: (1) sedimentary diagenetic stage, (2) hydrothermal ore-forming stage with three substages (I, II, and III), and (3) supergene stage. The hydrothermal stage II is the main economic mineralization stage.

The $\delta^{34} S$ values of sulfides in the Nanmushu deposit are characterized by positive values with a peak around $+18 \%$, and the reduced sulfur may have derived from reduction of $\mathrm{SO}_{4}{ }^{2-}$ from seawater and/or evaporitic sulfates. Thermochemical sulfate reduction (TSR) is the likely key factor for sulfur isotope fractionation during the ore-forming processes.

Ore-forming fluids are basinal brines, trapped in a heterogenous fluid system, with medium-low temperature $\left(107^{\circ}\right.$ to $340^{\circ} \mathrm{C}$ ) and medium-high salinity (up to $19 \mathrm{wt} . \% \mathrm{NaCl}$ equivalent). The majority of fluid inclusions are aqueoussalt dominant inclusions (type I) with minor hydrocarbonbearing inclusions (type II) with amount of $\mathrm{CH}_{4}, \mathrm{C}_{4} \mathrm{H}_{6}$, and bitumen. Microthermometric data exhibit temperature continuously decreased ( 171 to $340^{\circ} \mathrm{C}$ in stage $\mathrm{I}, 152$ to $276^{\circ} \mathrm{C}$ in stage II, and 107 to $202^{\circ} \mathrm{C}$ in stage III); however, the salinities maintain approximately the same at around 6 to $12 \mathrm{wt} . \% \mathrm{NaCl}$ equivalent in the two major ore-forming stages (I and II), and the salinities of barite-hosted FIs in stage III show a slight increase up to $19.0 \mathrm{wt} . \% \mathrm{NaCl}$ equivalent. These features suggest a mixing of higher salinity $\mathrm{CaCl}_{2} \pm \mathrm{MgCl}_{2}$ rich fluids into the original $\mathrm{H}_{2} \mathrm{O}-\mathrm{NaCl}$ with methane-rich fluid system. Different temperature-salinity fluids mixing and TSR could be the predominant factors to control the $\mathrm{Zn}-\mathrm{Pb}$ mineralization in the Nanmushu deposit.

\section{Conflicts of Interest}

The authors declare that there are no conflicts of interest regarding the publication of this paper.

\section{Acknowledgments}

This research was supported by projects from the National Natural Science Foundation of China (41603042 and 41672140), China Geological Survey (121201103094200), and the Fundamental Research Funds for the Central Universities, China University of Geosciences, Wuhan (CUGQYZX1733). The authors are grateful to Mr. Ying Ma and Qi-Zhi Chen and Dr. Man-Rong Jiang for helping with sample preparation and Professor Mou-Chun He for helping with Laser Raman spectroscopy analysis.

\section{References}

[1] J. S. Leventhal, "Organic matter and thermochemical sulfate reduction in the Viburnum Trend, southeast Missouri," Economic Geology, vol. 85, no. 3, pp. 622-632, 1990.

[2] P. F. Greenwood, J. J. Brocks, K. Grice et al., "Organic geochemistry and mineralogy. I. Characterisation of organic matter associated with metal deposits," Ore Geology Reviews, vol. 50, pp. 1-27, 2013.

[3] X. X. Gu, Y. M. Zhang, B. H. Li, S. Y. Dong, C. J. Xue, and S. H. Fu, "Hydrocarbon- and ore-bearing basinal fluids: A possible link between gold mineralization and hydrocarbon accumulation in the Youjiang basin, South China," Mineralium Deposita, vol. 47, no. 6, pp. 663-682, 2012. 
[4] G. Chi, C. Xue, X. Sun et al., "Formation of a giant $\mathrm{Zn}-\mathrm{Pb}$ deposit from hot brines injecting into a shallow oil-gas reservoir in sandstones, Jinding, southwestern China," Terra Nova, vol. 29, no. 5, pp. 312-320, 2017.

[5] W. Qi, M. T. Hou, K. M. Wang, and D. G. Wang, "A largescale stratabound lead-zinc metallogenic belt discovered in the Mayuan area," Regional Geology of China, vol. 23, pp. 1139-1142, 2004 (Chinese).

[6] B. Y. Chen, R. X. Li, H. Q. Liu, Y. N. Zhang, and S. W. Liu, "Geochemical charecteristics of Dengying dolomite in the Mayuan lead-zinc orefield, Nanzheng, Shaanxi," Bulletin and Mineralogy Petrology and Geochemistry, vol. 33, pp. 193-200, 2014 (Chinese).

[7] H. X. Wang, J. C. Xue, Z. M. Li, Q. Li, and R. J. Yang, "Geological and geochemical characteristics of Mayuan $\mathrm{Pb}-\mathrm{Zn}$ ore deposit on northern margin of Yangtze landmass," Mineral Deposits, vol. 27, pp. 37-48, 2008 (Chinese).

[8] S. Liu, R. Li, G. Chi, R. Zeng, L. Liu, and S. Shi, "Geochemical Characteristics and Sources of Ore-forming Fluids of the Mayuan Pb-Zn Deposit, Nanzheng, Shaanxi, China," Acta Geologica Sinica, vol. 89, no. 3, pp. 783-793, 2015.

[9] H.-M. Li, Y.-C. Chen, D.-H. Wang, and H.-Q. Li, "Geochemistry and mineralization age of the Mayuan zinc deposit, Nanzheng, southern Shaanxi, China," Geological Bulletin of China, vol. 26, no. 5, pp. 546-552, 2007 (Chinese).

[10] Y. Han, Y. Liu, S. Liu et al., "Origin of the breccia and metallogenic geological background of Mayuan $\mathrm{Pb}-\mathrm{Zn}$ deposit," Earth Science Frontiers, vol. 23, no. 4, pp. 94-101, 2016.

[11] Y. B. Gao, K. Li, B. Qian, W. Y. Li, M. C. Zheng, and C. G. Zhang, "Trace elements, S, Pb, He, Ar and C isotopes of sphalerite in the Mayuan $\mathrm{Pb}-\mathrm{Zn}$ deposit, at the northern margin of the Yangtze plate, China," Acta Petrologica Sinica, vol. 32, pp. 251-263, 2016 (Chinese).

[12] E. Roedder, "Fluid inclusions," Reviews in Mineralogy, vol. 12, pp. 1-644, 1984.

[13] R. J. Bodnar, "Revised equation and table for determining the freezing point depression of $\mathrm{H} 2 \mathrm{O}-\mathrm{Nacl}$ solutions," Geochimica et Cosmochimica Acta, vol. 57, no. 3, pp. 683-684, 1993.

[14] J. J. Wilkinson, "Fluid inclusions in hydrothermal ore deposits," Lithos, vol. 55, no. 1-4, pp. 229-272, 2001.

[15] H. Z. Lu, H. R. Fan, P. Ni, G. X. Ou, K. Shen, and W. H. Zhang, Fluid inclusion, Science Press, Beijing, China, 2004.

[16] M. Steele-MacInnis, R. J. Bodnar, and J. Naden, "Numerical model to determine the composition of $\mathrm{H} 2 \mathrm{O}-\mathrm{NaCl}-\mathrm{CaCl} 2$ fluid inclusions based on microthermometric and microanalytical data," Geochimica et Cosmochimica Acta, vol. 75, no. 1, pp. 2140, 2011.

[17] M. T. Hou, D. G. Wang, S. B. Deng, and Z. R. Yang, “Geology and genesis of the Mayuan lead-zinc mineralization belt in the Shaanxi Province," Northwestern Geology, vol. 40, pp. 42-60, 2007.

[18] H. C. Liu and W. D. Lin, Study on the law of Pb-Zn-Ag ore deposit in Northeast Yunnan, China, Yunnan University Press, Kunming, China, 1999.

[19] W.-H. Sun, M.-F. Zhou, J.-F. Gao, Y.-H. Yang, X.-F. Zhao, and J.-H. Zhao, "Detrital zircon U-Pb geochronological and $\mathrm{Lu}-\mathrm{Hf}$ isotopic constraints on the Precambrian magmatic and crustal evolution of the western Yangtze Block, SW China," Precambrian Research, vol. 172, no. 1-2, pp. 99-126, 2009.

[20] X.-F. Zhao, M.-F. Zhou, J.-W. Li et al., "Late Paleoproterozoic to early Mesoproterozoic Dongchuan Group in Yunnan, SW
China: Implications for tectonic evolution of the Yangtze Block," Precambrian Research, vol. 182, no. 1-2, pp. 57-69, 2010.

[21] S. Gao, J. Yang, L. Zhou et al., "Age and growth of the Archean Kongling terrain, South China, with emphasis on $3.3 \mathrm{GA}$ granitoid gneisses," American Journal of Science, vol. 311, no. 2, pp. 153-182, 2011.

[22] C. Zhang, Y. Wu, L. Hou, and J. Mao, "Geodynamic setting of mineralization of Mississippi Valley-type deposits in world-class Sichuan-Yunnan-Guizhou $\mathrm{Zn}-\mathrm{Pb}$ triangle, southwest China: Implications from age-dating studies in the past decade and the Sm-Nd age of Jinshachang deposit," Journal of Asian Earth Sciences, vol. 103, pp. 103-114, 2015.

[23] M. T. Hou, D. G. Wang, Z. R. Yang, and J. Gao, "Geological characteristics of lead-zinc mineralized zones in the Mayuan area, Shaanxi, and their ore prospects," Geology in China, vol. 34, pp. 101-109, 2007.

[24] R. H. Goldstein, "Petrographic analysis of fluid inclusion," Minerallogical Association of Canada, Short Course Handbook, vol. 32, pp. 9-54, 2003.

[25] R. J. Bodnar, "Reequilibration of fluid inclusions," in Fluid inclusions: Analysis and Interpretation, I. Samson, A. Anderson, and D. Marshall, Eds., vol. 32 of Mineralogical Association of Canada Short Course Series, pp. 213-230, 2003.

[26] E. A. J. Burke, "Raman microspectrometry of fluid inclusions," Lithos, vol. 55, no. 1-4, pp. 139-158, 2001.

[27] R. H. Goldstein and T. J. Reynolds, Systematics of Fluid Inclusions in Diagenetic Minerals, SEPM (Society for Sedimentary Geology), 1994.

[28] C. S. Oakes, R. J. Bodnar, and J. M. Simonson, "The system $\mathrm{NaClCaCl} 2 \mathrm{H} 2 \mathrm{O}$ : I. The ice liquidus at 1 atm total pressure," Geochimica et Cosmochimica Acta, vol. 54, no. 3, pp. 603-610, 1990.

[29] D. L. Leach, D. C. Bradley, D. Huston, S. A. Pisarevsky, R. D. Taylor, and S. J. Gardoll, "Sediment-hosted lead-zinc deposits in earth history," Economic Geology, vol. 105, no. 3, pp. 593-625, 2010.

[30] S. A. Gleeson, J. J. Wilkinson, F. M. Stuart, and D. A. Banks, "The origin and evolution of base metal mineralising brines and hydrothermal fluids, South Cornwall, UK," Geochimica et Cosmochimica Acta, vol. 65, no. 13, pp. 2067-2079, 2001.

[31] R. Thiéry, "Thermodynamic modelling of aqueous CH4bearing fluid inclusions trapped in hydrocarbon-rich environments," Chemical Geology, vol. 227, no. 3-4, pp. 154-164, 2006.

[32] J. Conliffe, D. H. C. Wilton, N. J. F. Blamey, and S. M. Archibald, "Paleoproterozoic Mississippi Valley Type $\mathrm{Pb}-\mathrm{Zn}$ mineralization in the Ramah Group, Northern Labrador: Stable isotope, fluid inclusion and quantitative fluid inclusion gas analyses," Chemical Geology, vol. 362, pp. 211-223, 2013.

[33] B. S. Lollar, G. Lacrampe-Couloume, G. F. Slater et al., "Unravelling abiogenic and biogenic sources of methane in the Earth's deep subsurface," Chemical Geology, vol. 226, no. 3-4, pp. 328339, 2006.

[34] B. S. Lollar, G. Lacrampe-Couloume, K. Voglesonger, T. C. Onstott, L. M. Pratt, and G. F. Slater, "Isotopic signatures of $\mathrm{CH} 4$ and higher hydrocarbon gases from Precambrian Shield sites: A model for abiogenic polymerization of hydrocarbons," Geochimica et Cosmochimica Acta, vol. 72, no. 19, pp. 4778-4795, 2008.

[35] S. Salvi and A. E. Williams-Jones, "Fischer-Tropsch synthesis of hydrocarbons during sub-solidus alteration of the strange lake peralkaline granite, Quebec/Labrador, Canada," Geochimica et Cosmochimica Acta, vol. 61, no. 1, pp. 83-98, 1997. 
[36] J. Potter, A. H. Rankin, and P. J. Treloar, "Abiogenic FischerTropsch synthesis of hydrocarbons in alkaline igneous rocks; fluid inclusion, textural and isotopic evidence from the Lovozero complex, N.W. Russia," Lithos, vol. 75, no. 3-4, pp. 311330, 2004.

[37] Y. A. Taran, G. A. Kliger, and V. S. Sevastianov, "Carbon isotope effects in the open-system Fischer-Tropsch synthesis," Geochimica et Cosmochimica Acta, vol. 71, no. 18, pp. 4474-4487, 2007.

[38] P. Mougin, V. Lamoureux-Var, A. Bariteau, and A. Y. Huc, “Thermodynamic of thermochemical sulphate reduction," Journal of Petroleum Science and Engineering, vol. 58, no. 3-4, pp. 413-427, 2007.

[39] N. I. Basuki, B. E. Taylor, and E. T. C. Spooner, "Sulfur isotope evidence for thermochemical reduction of dissolved sulfate in Mississippi Valley-type zinc-lead mineralization, Bongara area, Northern Peru," Economic Geology, vol. 103, no. 4, pp. 783-799, 2008.

[40] U. Herlec, J. E. Spangenberg, and J. V. Lavrič, "Sulfur isotope variations from orebody to hand-specimen scale at the Mežica lead-zinc deposit, Slovenia: A predominantly biogenic pattern," Mineralium Deposita, vol. 45, no. 6, pp. 531-547, 2010.

[41] J. Carrillo-Rosúa, A. J. Boyce, S. Morales-Ruano et al., "Extremely negative and inhomogeneous sulfur isotope signatures in Cretaceous Chilean manto-type $\mathrm{Cu}-(\mathrm{Ag})$ deposits, Coastal Range of central Chile," Ore Geology Reviews, vol. 56, pp. 13-24, 2014.

[42] H. Ohmoto and R. O. Rye, "Isotopes of sulfur and carbon," in Geochemistry of Hydrothermal Ore Deposits, H. L. Barnes, Ed., pp. 509-567, Wiley, New York, NY, USA, 2nd edition, 1979.

[43] M. Chaussidon, F. Albarède, and S. M. F. Sheppard, "Sulphur isotope variations in the mantle from ion microprobe analyses of micro-sulphide inclusions," Earth and Planetary Science Letters, vol. 92, no. 2, pp. 144-156, 1989.

[44] G. E. Claypool, W. T. Holser, I. R. Kaplan, H. Sakai, and I. Zak, "The age curves of sulfur and oxygen isotopes in marine sulfate and their mutual interpretation," Chemical Geology, vol. 28, pp. 199-260, 1980.

[45] T. Zhang, X. Chu, Q. Zhang, L. Feng, and W. Huo, "The sulfur and carbon isotopic records in carbonates of the Dengying Formation in the Yangtze Platform, China," Acta Petrologica Sinica, vol. 20, no. 3, pp. 717-724, 2004.

[46] H. G. Machel, "Bacterial and thermochemical sulfate reduction in diagenetic settings - old and new insights," Sedimentary Geology, vol. 140, no. 1-2, pp. 143-175, 2001.

[47] J.-X. Zhou, J.-H. Bai, Z.-L. Huang, D. Zhu, Z.-F. Yan, and Z.C. Lv, "Geology, isotope geochemistry and geochronology of the Jinshachang carbonate-hosted $\mathrm{Pb}-\mathrm{Zn}$ deposit, southwest China," Journal of Asian Earth Sciences, vol. 98, pp. 272-284, 2015.

[48] G. M. Anderson, "The mixing hypothesis and the origin of Mississippi valley-type ore deposits," Economic Geology, vol. 103, no. 8, pp. 1683-1690, 2008.

[49] D. L. Leach, D. Bradley, M. T. Lewchuk, D. T. A. Symons, G. De Marsily, and J. Brannon, "Mississippi Valley-type lead-zinc deposits through geological time: Implications from recent agedating research," Mineralium Deposita, vol. 36, no. 8, pp. 711740, 2001.

[50] S. E. Kesler, M. Reich, and M. Jean, "Geochemistry of fluid inclusion brines from Earth's oldest Mississippi Valley-type (MVT) deposits, Transvaal Supergroup, South Africa," Chemical Geology, vol. 237, no. 3-4, pp. 274-288, 2007.
[51] M. S. Appold and Z. J. Wenz, "Composition of ore fluid inclusions from the Viburnum Trend, Southeast Missouri district, United States: Implications for transport and precipitation mechanisms," Economic Geology, vol. 106, no. 1, pp. 55-78, 2011.

[52] Y. L. Chen, X. L. Chu, X. L. Zhang, and M. G. Zhai, "Carbon isotopes, sulfur isotopes, and trace elements of the dolomites from the Dengying Formation in Zhenba area, southern Shaanxi: Implications for shallow water redox conditions during the terminal Ediacaran," Science China Earth Sciences, vol. 58, no. 7, pp. 1107-1122, 2015.

[53] T. Qian, S. Liu, W. Li, T. Gao, and X. Chen, "Early-Middle Jurassic evolution of the northern Yangtze foreland basin: A record of uplift following Triassic continent-continent collision to form the Qinling-Dabieshan orogenic belt," International Geology Review, vol. 57, no. 3, pp. 327-341, 2015.

[54] Y. Wu, C. Zhang, J. Mao, H. Ouyang, and J. Sun, "The genetic relationship between hydrocarbon systems and Mississippi Valley-type $\mathrm{Zn}-\mathrm{Pb}$ deposits along the $\mathrm{SW}$ margin of Sichuan Basin, China," International Geology Review, vol. 55, no. 8, pp. 941-957, 2013.

[55] M. Corbella, C. Ayora, and E. Cardellach, "Hydrothermal mixing, carbonate dissolution and sulfide precipitation in Mississippi Valley-type deposits," Mineralium Deposita, vol. 39, no. 3, pp. 344-357, 2004.

[56] D. C. Bradley and D. L. Leach, "Tectonic controls of Mississippi Valley-type lead-zinc mineralization in orogenic forelands," Mineralium Deposita, vol. 38, no. 6, pp. 652-667, 2003. 

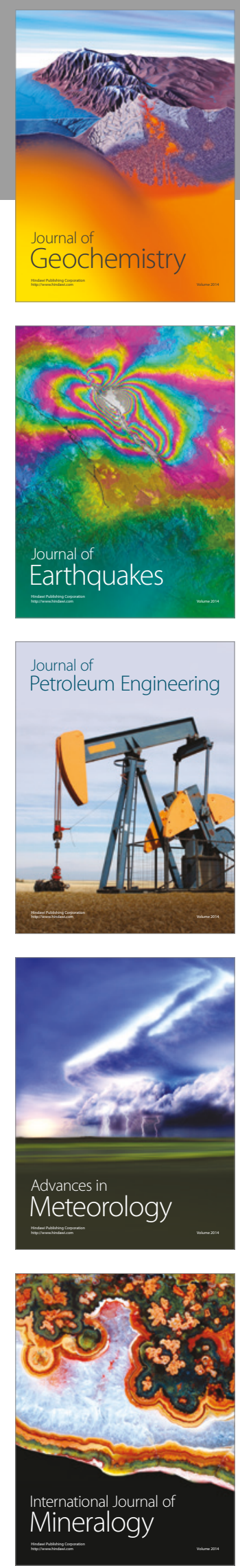
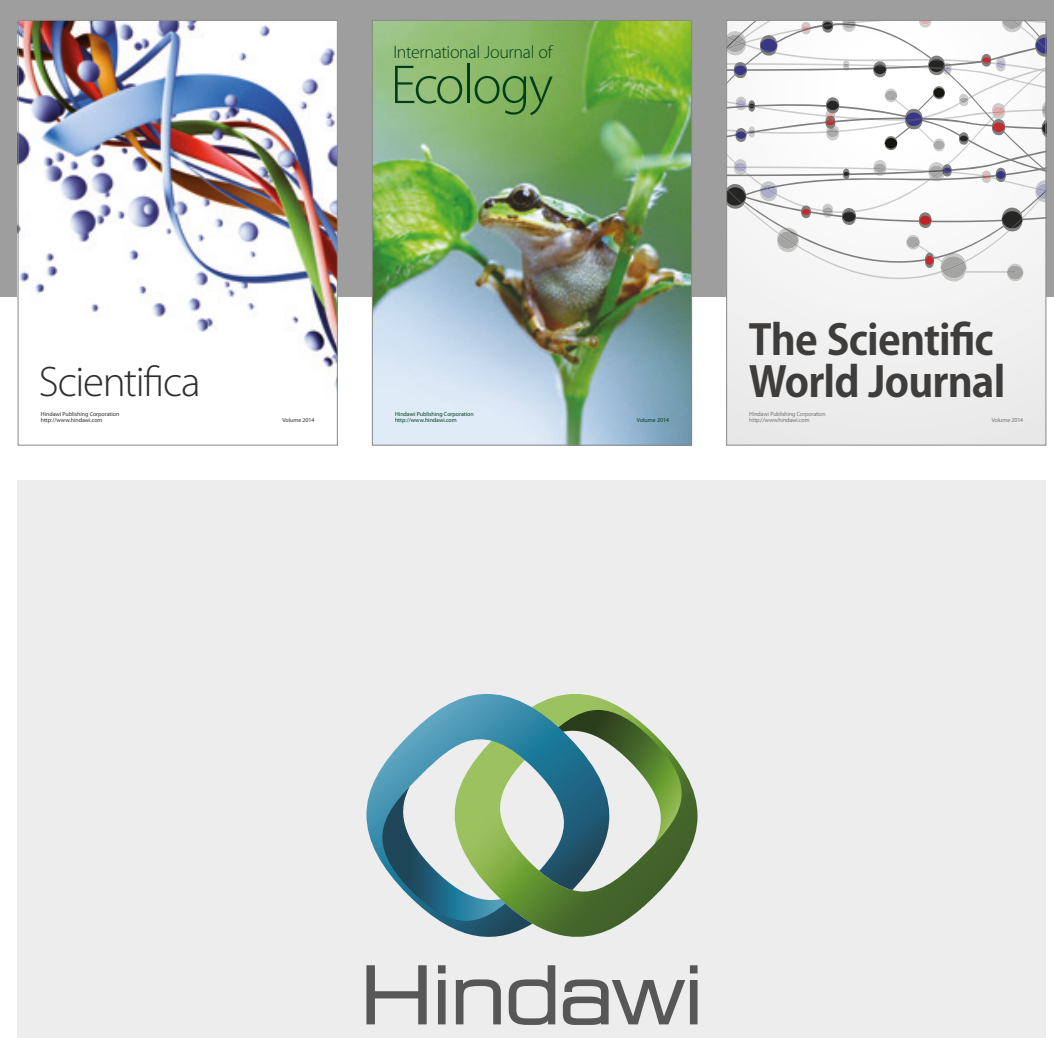

Submit your manuscripts at

https://www.hindawi.com
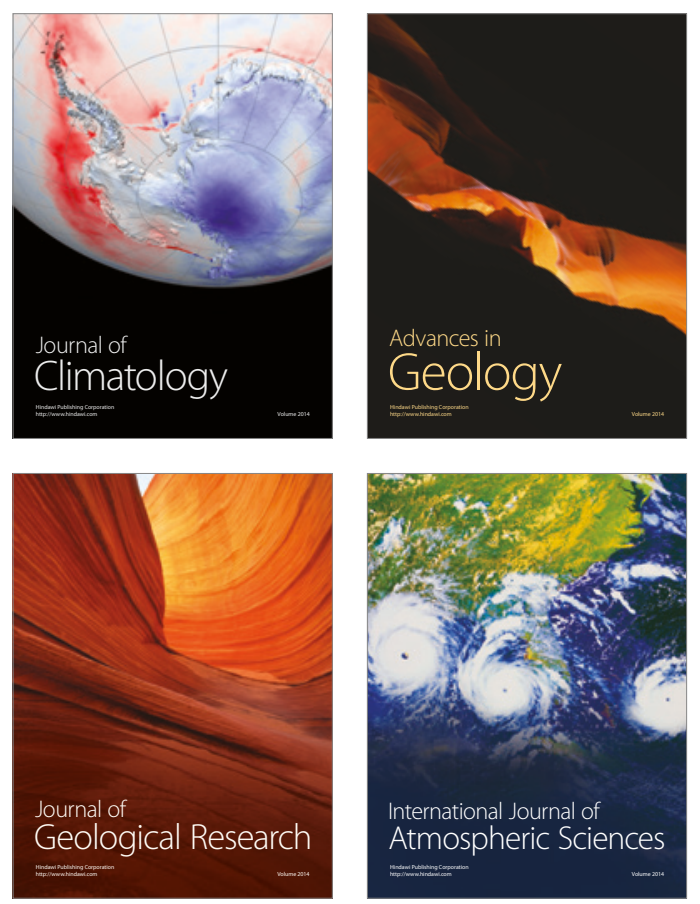

The Scientific

World Journal
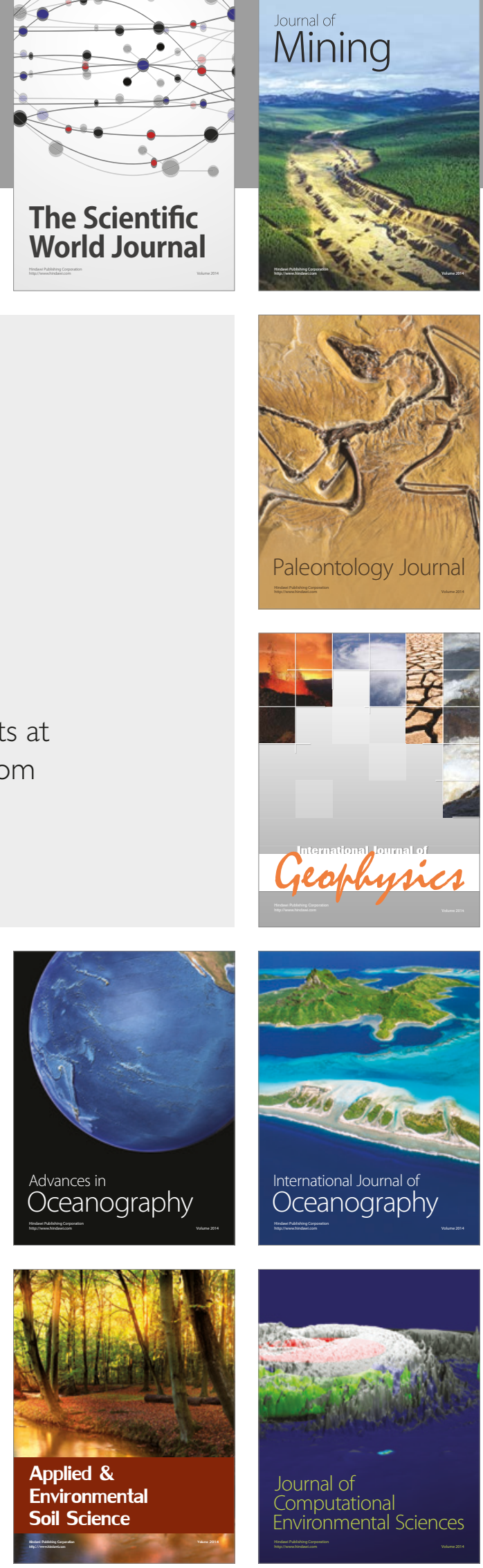